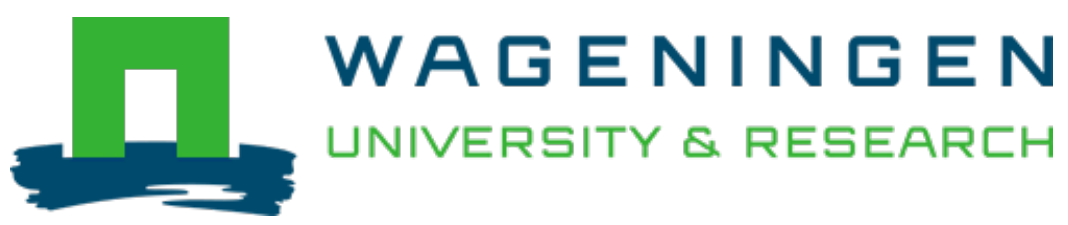

\title{
Social acceptability of radical food innovations
}

Food Technology Disruptions

Fischer, A.R.H.; Loo, E.J.

https://doi.org/10.1016/B978-0-12-821470-1.00002-1

This publication is made publicly available in the institutional repository of Wageningen University and Research, under the terms of article $25 \mathrm{fa}$ of the Dutch Copyright Act, also known as the Amendment Taverne. This has been done with explicit consent by the author.

Article $25 \mathrm{fa}$ states that the author of a short scientific work funded either wholly or partially by Dutch public funds is entitled to make that work publicly available for no consideration following a reasonable period of time after the work was first published, provided that clear reference is made to the source of the first publication of the work.

This publication is distributed under The Association of Universities in the Netherlands (VSNU) 'Article $25 \mathrm{fa}$ implementation' project. In this project research outputs of researchers employed by Dutch Universities that comply with the legal requirements of Article $25 \mathrm{fa}$ of the Dutch Copyright Act are distributed online and free of cost or other barriers in institutional repositories. Research outputs are distributed six months after their first online publication in the original published version and with proper attribution to the source of the original publication.

You are permitted to download and use the publication for personal purposes. All rights remain with the author(s) and / or copyright owner(s) of this work. Any use of the publication or parts of it other than authorised under article $25 \mathrm{fa}$ of the Dutch Copyright act is prohibited. Wageningen University \& Research and the author(s) of this publication shall not be held responsible or liable for any damages resulting from your (re)use of this publication.

For questions regarding the public availability of this publication please contact openscience.library@,wur.nl 


\title{
Chapter 9
}

\section{Social acceptability of radical food innovations}

\author{
Arnout R.H. Fischer, Ellen J. Van Loo \\ Wageningen University, Marketing, and Consumer Behaviour Group, Wageningen, \\ The Netherlands
}

\subsection{Introduction}

The food market has long been hinging on two opposing stories: convenient and processed food versus authentic, traditional foods. Society has been fascinated by the idea of convenient, high tech foods, such as the food pills for consumers illustrated by the space-age Jetsons cartoon originating in the 1960s, which, although nightmarish to many, still captures interest (Belasco, 2000). Another, probably better known, imaginary high-tech food production system is Star-Trek's food replicator that can create any kind of traditional food and beverage by request. The food replicator is an adaptation of food-synthesizers from the Original Star-Trek series, which created cubes of nutrient-rich foods, not unlike the Jetson's food pills. The change from the original cubes of nutrients toward more traditional foods (according to the Star-Trek show a series of improvements between the 22nd and 24th centuries; Belasco, 2000) already indicates that society may not be ready for food pills or food cubes. This links to the second story where consumers and society view good food and farming practices in a romantic, traditional perspective (e.g., Mazzacano D'Amato \& Falzon, 2015) of free-ranging animals and flowering alpine meadows.

This dual story puts pressure on food innovation systems, which likely influences the success and failure of radical innovations in agri-food businesses. However, even the romantic view on farming practices is likely the outcome of previous radical innovations in the food supply. Perhaps the most societally radical innovation has been the domestication of plants and animals, thought to have occurred at the end of the Pleistocene. The more predictable food stocks supported the permanent colonization of suitable habitats and the creation of static, permanent, and broader communities, which lead to radical changes in human societies (Diamond, 2002). Through 
innovations that introduced more complex preparation methods like cooking and fermentation, humans gained access to otherwise inedible or indigestible foods and food ingredients (Hillman \& Davies, 1990). These innovations radically changed the process of food production, preparation, and storage, and hence, changed the dietary patterns of humans. Not only in prehistoric times but also in historical times, important innovations radically changed society. The introduction of the moldboard plow in early medieval Europe allowed the European population to farm fertile but challenging to manage lands, such as those containing heavy clay, at manageable input of labor. It has been argued that the introduction of these plowing systems played a pivotal role in Western European recovery from the period of scarcity and population reduction after the collapse of the Roman Empire. The increased food production allowed the growth of cities from about the 10th century CE (Gimpel, 1992). Wind and watermills further provided energy sources required for these cities to flourish and develop economies based on mechanical power sources, making them completely different than those in the classical antiquity.

Radical innovations have continued to influence agricultural practices into modern times. The introduction of mechanized farming in the 19th century increased food production, and reduced labor demand in agriculture resulted in the movement of populations from rural to urban environments. In the early 20th century, the development of internal combustion engines led to the development of tractors and other mechanization of agriculture. At the same time, chemical fertilizers and pesticides were developed, which heralded the "green revolution" (Evenson \& Gollin, 2003). The innovations during the green revolution resulted in crops being produced consistently in volumes unparalleled in history. The consistent crop quality and sufficiency reduced the probability of famines and hugely increased yields on arable lands; thus, breaking the then-current Malthusian predictions about the food capacity of the earth. The green revolution allowed for much of the world population growth in the 20th century.

The efficiency advocated and achieved by introducing mechanized agriculture, and consistent crop support resulted in food becoming a commodity market, where large volumes of very similar resources are pooled and shipped around the world with small profit margins. To increase profit margins, identification of a specific niche or creation of a brand to distinguish products from competitors has been an ongoing effort by food producers. Food has become one of the markets where brands and brand image provide the most added value. The brand name Coca-Cola for example, originated in 1886, and through consistent advertising campaigns, has been associated with the happy American family life. The creation of Christmas advertisements dressing Santa Claus in Coca-Cola company's colors, red and white, has even shaped the American, and later global image of Santa Clause (Mckay, 2008). The CocaCola brand is considered a highly valuable asset of the Coca-Cola company (Fischer \& Himme, 2017), with the value of the name alone being estimated 
between 50 and 80 billion US\$ in 2010 (depending on sources and estimation methods). More recently, the primary production of agriculture has also started to diversify and trying to create specific niche markets for their specific products outside commodity streams (Meulenberg \& Viaene, 2005), for example, by creating branded vegetables and fruits such as the Zespri kiwi fruit. This approach requires radical reorganization of resource streams as niche products need to be kept separate from commodities.

The radical and often transformative innovations that agricultural production and marketing have gone through has not always been unopposed. The Luddite movement of the late 18th and early 19th century included farmworker protests voicing their concern about changes in traditional employment and ways of living driving farm laborers to seek employment in industries (Sale, 1996). These protests were, in the light of labor conditions and pollution of the major cities at the time of the industrial revolution, not necessarily unwarranted. Nowadays, the term Luddite remains in use as a generally derogatory term to refer to individuals or groups that oppose innovation. While famines and the world wars of the early 20th century raised the need for innovation to ensure food security, by the time the high-tech utopia as fantasized in the Jetsons and Star-Trek came to the fore, societal concerns were once again gaining attention. Concerns about the harmful effects of agrochemicals on human health and nature increased signaled by the publication of "the silent spring" by Rachel Carson in (1962). Carson used the metaphor that the increase in pesticide use resulted in fewer bird sounds heard in agricultural areas. This book is considered as a landmark of environmentalists' movement in the latter half of the 20th century. More recently, concerns have been expressed about the replacement of natural ecosystems such as the replacement of natural rainforest by monocultures of soy or palm crops. Other societally controversial innovations in the agri-food sector have led to societal protest, to the extent that these technologies suffered delayed introduction and were introduced at much more limited scales than initially envisaged. For example, the introduction of irradiated foods relatively close in time to the widespread destruction of crops as far away as Sweden $(\sim 1500 \mathrm{~km})$ to counter the radiation by pollution after the 1986 Chernobyl accident resulted in general public rejection of irradiation of food (for example, see: Bruhn, 1995). The development and introduction of genetically modified foods and crops where all primary benefits accrued to multinationals, pesticide producers, and other actors in the production chain resulted in significant protests and stringent regulations initially in Europe and later elsewhere (Frewer et al., 2013, among others). The food industry has been trying to buy in on the trend for natural rather than high tech food in society. Images of grandmothers preparing traditional foods or rainforests where traditional local agriculture provides sought after resources are some of many romanticized claims of authentic, low tech, traditional production in food. Brands like Unilever's Bertolli or Associated British Food's Patak gain much of their value 
from the attention to traditional products and are advertised with direct reference to traditional agriculture and authentic preparation methods. Other brands have also been increasingly capitalizing on the growing societal demand for more authentic products (Askegaard \& Brogård, 2016). Over the last decades, such authenticity branding has played an essential role in de-commodifying food markets. This increased attention to authenticity has been an incremental process making it more difficult for radical innovations that cannot be aligned with images of authenticity to enter the market.

While radical innovations in food production systems have been ongoing since the dawn of time, in the current era, resistance to further acceptance and adoption of such technologies in the production of foods remains substantial. Nevertheless, radical innovations in the food system are emerging. Internet technology allows consumers and citizens to access information and sometimes even video footage of production systems, Internet marketing allows for new ways of ordering foods and keeping track of consumer stocks, and despite some concerns, consumers do not seem reluctant about these innovations.

Before providing an overview of the ways how society deals with disruptive and radical innovations, first, there is a need to clarify some of the terms in use. Much of the literature on the acceptance of innovations and new products or services based on technological innovations is about acceptance. However, the word "acceptance" is used in various ways (Fischer \& Reinders, 2016; Ronteltap, Fischer, \& Tobi, 2011). In marketing and product innovation literature, the term "acceptance of a novel product" is generally used to indicate that the innovation has become part of society and is actively being used (Rogers, 1962/1995). In the public understanding of science and risk analysis literature, "acceptance of an innovation" relates more to tolerance (cf. Taebi, 2017) of the innovation, which is not so much acceptance in daily behavior, but more a tacit or psychological acceptance indicating that people do not categorically reject the innovation (see, e.g., the studies of Bredahl, 2001; Schenk et al., 2011; Siegrist, 2000). Regardless of whether acceptance is considered actual use of an innovation or the psychological acceptance of that innovation, in both cases, the underlying assumption is that there is an innovation that enters society, and only after its introduction society accepts or rejects the innovation. Alternatively, to put it more directly, the burden of accepting the innovation lies with society. This fact may easily lead to "blaming" society for not accepting an innovation deemed brilliant in the mind of the developers of that innovation. This approach to public or societal acceptance, prevalent in innovation acceptance literature, foregoes the fact that to be accepted, an innovation needs to be acceptable (Taebi, 2017). Although the linguistic difference between acceptance and acceptability seems small, we should not underestimate the consequence of the subtle difference. Acceptability, in contrast to acceptance, is not an act of society, but a built-in property of the innovation. It cannot be achieved by merely informing or educating consumers, but must be built into the fabric of innovation. The burden of 
creating a societally acceptable innovation lies with developers, not the public. How to create such acceptable innovations can still be informed by the broader literature on acceptance to identify what society is sensitive about, but then, this needs to be translated into the innovation itself.

The challenge is to align with the demand by consumers and society for foods and food services that fit in their modern lifestyles on the one hand and align with the demand for natural and authentic products and production chains on the other hand. It is essential to consider societal drivers, general scientific knowledge about consumer and societal response to innovations, and then reflect upon some current innovations. This chapter aims to provide such an overview.

Therefore, we will briefly introduce some drivers that influence consumers in 2020 to make choices, change choices, or decide on the desirability of innovations in the food market. Reference to a specific time frame is related to the trend that, especially in developed countries, high levels of food security and food safety combined with rising welfare levels resulted in more focus on health and sustainability since the 1990s (Kambewa, 2007). The emergence of the Internet combined with the rapidly decreasing cost of sensors to measure personal health and nutritional needs and the emergence of new generations of the millennials and Generation Z, for whom sustainability is central to their lifestyle, has opened the food market for disruptive developments, discussed throughout this book.

\subsection{Consumers in the early $2020 \mathrm{~s}$}

To determine societal acceptability, we need to consider that what may have been acceptable to our parents' parents may not be acceptable to us. The view of what is acceptable slowly changes in society, and this is often related to the time in which one is raised, i.e., the cohort one belongs to (Buss, 1974). In the early 2020s, the Millennial generation (born between approximately 1985 and 2000) has become a dominant force in the marketplace. The millennials, next to generation $\mathbf{X}$, the generation preceding the millennials with birth years starting from 1965 and the baby-boomers (born 1945-1965) complement (the majority of) the adult population. The next generation, "Generation Z" (born from about 2000), is starting to mature and gaining influence. The delineation between cohorts differs between definitions and is not strict. Those born in 1965 and 1966 are often classified in different cohorts but (obviously) have more in common than those born in 1966 and 1984 (classified in the same cohort).

Nevertheless, considering cohorts as distinct can provide some insights into how society responds to innovations. To understand how society will respond to innovations, considering these cohorts in the light of technology generations and the years when people develop their character, worldview, and personality (roughly until their mid-20s) would be useful. In terms of technology generations, baby-boomers were raised in the precomputer age and were exposed to 
computers only in later life. While baby-boomers may have embraced computers and the Internet, this is not recognizable from their youth. Generation $\mathrm{X}$ can be considered the first computer generation raised during the emergence of programmable (home) computers and to whom computers are a visible part of life (Dimock, 2019). Millennials are the first Internet generation (Dimock, 2019) raised when the Internet was ubiquitous, and people started to be connected from a young age (Sackmann \& Winkler, 2013). Baby-boomers were raised during Cold War tensions between the USSR and the West. However, the baby-boomers experienced the thriving economies and countercultures of the 1960s and watched the first human walking on the moon. Generation X was reaching adulthood during the recession in the 1980s and adopted a more cynical approach to society (Fishman, 2016). Generation X was also growing up when the Cold War ended, and the Berlin wall fell. The next cohort, Millennials, grew up during the booming economy of the 1990s, but also experienced the 9/11 attacks, the subsequent start of the war on terror and the 2008 economic crisis (Dimock, 2019). Millennials are shown to be the least quality and most prestige focused of the current cohorts (Moore \& Carpenter, 2008), but the millennial cohort also contains substantial subgroups who focus on ethical consumption and cause-based purchasing (Bucic, Harris, \& Arli, 2012). It remains hard to capture the identity of the newest generation, "Generation Z," as that generation is still developing and seems rather diverse. Generation $\mathrm{Z}$ is the generation that is becoming adult in a world where Internet is ubiquitous from a young age, and while their views are in many respects similar to these of millennials, they are demanding more government intervention in societal issues compared to previous cohorts (Parker, Graf, \& Igielnik, 2019). How the substantial government interventions, including forced lockdown of many countries, the struggling health care systems, and the dramatic increase in distance learning and working from home during the 2020 COVID-19 pandemic will influence this generation's worldview is yet unknown. However, it makes sense to assume this will be an essential part of their formative experiences.

Population cohorts and the changing consumer positions influence more short-term consumer trends. Such trends can give insight into what societal priorities are relevant for current innovations to be societally acceptable. Ten global food trends for 2020 were identified by market research agency Innova (Williams, 2019). About six out of the ten main trends involve technologies or food contents that are a disruptive departure of traditional food markets. Consumers increasingly demand transparency about the provenance of ingredients, and they want to be able to verify this, which requires accurate and specific tracking and tracking technologies and may require redesign or even novel production methods. The consumer is moving away from animal products to plant-based alternatives, even if they are not vegans or vegetarians, which requires the development of high-quality alternatives to animal products. Society expects companies to invest in sustainability, reduce food and plastic 
(packaging) waste, which requires radical changes in the way how products and packaging are designed, and how waste is dealt with. The society also places a burden on consumers to better manage their food supply and limit household food waste. Individual consumers demand foods that are healthy, convenient, and provide pleasure. This trend, related to health, paves the way for a new generation of functional foods and the growth in demand for supplements, e.g., powdered protein drinks. Increased attention for pleasurable experience and convenience may further increase the demand for ready-to-eat meals, but also meal boxes and a shift to digital marketing of food. Increased focus on named known ingredients, as mistrust in artificial additives remains, society calls for clean labels with few ingredients which they know, can recognize and interpret their relevance (also see Lion, Willems, Fischer, \& van Trijp, 2020). Increased personalization or limited releases asking for foods tailored to individual preference or even individual nutritional profile, which requires made to order foods and keeping track of personal preferences and needs.

\subsection{Societal responses to radical innovation}

\subsubsection{Generic individual and cultural influences}

Several theories have been developed to assess consumer response to innovations (Ronteltap et al., 2011). Among the most frequently used is the Theory of Planned Behavior (TPB) (Ajzen, 1991), which is a further development of the Theory of Reasoned Action (TRA) (Fishbein \& Ajzen, 1975). The Theory of Planned Behavior posits that behavior follows from a behavioral intention (plan) to conduct that behavior; under the condition that people think they have, and they also actually have the control to engage in that behavior. Behavioral intention is determined by attitudes, social norms, and perceived behavioral control. Attitudes are summary evaluations in terms of an overall positive or negative opinion about an attitude object. Attitudes are based on beliefs about how product properties either positively or negatively contribute to the overall product performance. Social norms depend on beliefs and evaluations about social approval of conducting the behavior by relevant peers such as family, colleagues, and friends. "I have perceived behavioral control results from beliefs and evaluations of the likelihood that the behavior is under the control of the individual" (Ajzen, 1991). Perceived behavioral control has two roles in the model. Perceived behavioral control contributes to the formation of an intention: "If I do not believe I can do it, I will not form an intention." The second role relates to whether intention results in actual behavior: "If at the moment of action I do not believe I can do it, I will not follow my intention and will not execute the planned behavior."

While the Theory of Planned Behavior was not developed to investigate novel products or disruptive innovations, it is among the most frequently used theories and is applied straightforwardly to novel foods including potentially disruptive innovations (e.g., Saba \& Vassallo, 2002) such as insect-eating 
(Menozzi, Sogari, Veneziani, Simoni, \& Mora, 2017). The Theory of Planned Behavior can accommodate the study of innovations because it includes the personal opinion (attitude) of the person forming an intention, but also includes their assessment of peer approval (or peer pressure) to engage in the behavior and an assessment of the likelihood they actually can engage in the behavior. This fact allows people to position innovation adoption behavior in the social context. The versatility and general applicability of the Theory of Planned Behavior also have downsides. Most importantly, while within the Theory of Planned Behavior intentions are generally well predicted, mainly by attitudes, the actual behavior is much less predictable, resulting in the still unresolved attitude-behavior gap (e.g., Vermeir \& Verbeke, 2006; Yamoah \& Acquaye, 2019). There are some reasons for this attitude-behavior gap. The first reason is that the Theory of Planned Behavior is often used for unplanned, automatic, or habitual behaviors. These unplanned behaviors are considered to be outside the scope of the theory (Verplanken \& Orbell, 2003). A second reason is that in many cases, general attitudes, social norms, and perceived behavioral controls are used, which because of their general nature, are unlikely to predict specific behaviors well (Kaiser, Schultz, \& Scheuthle, 2007). Kaiser further argues that if attitudes were to be measured at the same level of specificity, compatible with the behavior, the prediction of behavior improves a lot. In the case of disruptive innovations, however, we argue that consumer response to a large extent has to do with general information at first and that, particularly in the food domain, much of the behaviors are nonplanned. Therefore, the application of the Theory of Planned Behavior for disruptive innovations in food should be applied with care.

Another frequently used model to explain the response to innovations is the Technology Acceptance Model (TAM) (Davis, 1989). The Technology Acceptance Model shares many properties with the Theory of Planned Behavior. Like the Theory of Planned Behavior, it predicts the use of technology from attitudes and intentions toward using that technology. An essential difference between the Technology Acceptance Model and the Theory of Planned Behavior lies in the determinants of the attitudes. The Technology Acceptance Model was developed based on the first generations of programmable consumer products entering mass markets in the 1980 (most infamously VCR (video cassette recorder) systems). Before the 1980s, such complex systems were mostly reserved for professional experts or at bestdedicated hobbyists; hence, expert knowledge to operate the interface could be assumed. Once programmable VCRs entered the market, novice users became operators. To predict the kind of interfaces that would be accepted, the Technology Acceptance Model strongly focusses on Perceived Usefulness (i.e., does the apparatus deliver what I want of it) and Ease of Use of the technology. Since its original conception, the Technology Acceptance Model has been extended to a TAM-2 and TAM-3 with additional predictors of perceived usefulness and perceived ease of use (Venkatesh \& Bala, 2008; 
Venkatesh \& Davis, 1996, 2000; Venkatesh, Thong, \& Xu, 2012). TAM and its variants are widely used to explain the adoption of electronic devices and services with some success (Scherer, Siddiq, \& Tondeur, 2019). Elements of the Technology Acceptance Model formed the core of a comprehensive model: the Unified Theory of Acceptance and Use of Technology (UTAUT) (Venkatesh et al., 2012; Venkatesh, Morris, Davis, \& Davis, 2003). UTAUT aims to predict not only the original acceptance of new technology but also its continued use. It brings in social norms, demographics, and elements from other technology adoption models together with ideas of TAM. This fact resulted in a model with several dozens of independents variables. While this abundance of predictors necessarily improves expressive power, using UTAUT in practice results in having to measure so many variables to make practical use often infeasible. Besides this practical limitation, there can also be some doubt whether the addition of this many variables may lead to predictions that fit the observed data patterns quite well, but does not help in prioritization of prominent issues, or even worse, the abundance of predictors may obscure fundamental knowledge gaps related to core elements of the deliberation process (Bagozzi, 2007).

Whereas the TPB and TAM set the individual decision-maker at a central position, disruptive innovations unavoidably also contain a group dynamic. A central theory in this field is that of Diffusion of Innovation (Rogers, 1962/ 1995). This theory, originating in the 1960s, was based on how innovations diffused in society, and the initial studies included disruptive food technologies such as the mechanization of agriculture. Within the diffusion of innovations approach, different types of adapters are identified. Innovators are a small group of people or organizations that adopt an innovation when it is first available. At this stage of the innovation, it remains uncertain whether the innovation will succeed or fail, and innovators take some risk in embracing it. From innovation development, it would be useful to involve such innovators in the development process to ensure the innovation fits their expectations. The lead user approaches aim to bring in such early end-user input to codevelop products or services with the earliest users (von Hippel, 1986). Arguably, such lead users would most fit the innovator group or at least a second group of people adopting an innovation. This second group to embrace innovation is labeled as early adopters. Early adopters buy into the mature innovation, and if they appreciate the innovation, they can become opinion leaders. The emergence of vloggers and product placement in their Internet broadcasts capitalizes on the opinion leaders of this new generation of celebrities (Lin, Bruning, \& Swarna, 2018). The next group to adopt are early and late majorities, at which stage the innovation becomes commonplace, followed by laggards who are among the last to adopt the innovation. While the studies by Rogers and the subsequently developed mathematical models to describe the diffusion across the different user groups (Bass, 1969) describe innovators as about $2.5 \%$ of the market, early adopters about $13.5 \%$ and both majorities 
roughly $34 \%$ leaving $16 \%$ for the laggards, there are some issues in using the distinction between user groups to predict the diffusion of innovation. The main issue is that generally, the transitions between innovators, early adopters, early and late majorities, and laggards are determined after the market is saturated. At the moment of an evolving market, it is generally not possible to estimate whether the end-users buying into a product is an early adopter (predicting rapid growth of future uptake) or early or even late majorities (predicting a decreasing growth in demand). This fact is because the market potential of innovation may not be known at first. Hopefully, it is more than a tiny niche group, but almost certainly it will fall shy of the population as a whole. As a consequence, much of the research on innovation diffusion takes a reflective approach, describing specifics of an innovation trajectory. While this is very relevant in understanding what happened afterward, the predictive power of the findings from such an approach for future success or failure of innovations is limited (Claudy, Garcia, \& O'Driscoll, 2015).

Nevertheless, the diffusion of innovations has identified five determinants that can be used to predict whether an innovation is likely to be successfully adopted in the market: (i) relative advantage, i.e., delivering a benefit to the user over preceding technologies, (ii) compatibility, i.e., fitting with values, experiences, and needs of potential adopters, which is where radical innovations often face a challenge, (iii) complexity, more or less the opposite of ease of use, the central element in the TAM model introduced previously, (iv) trialability, i.e., the possibility to experiment with innovation before actually committing to buying and implementing it in the long run and (v) observability by others. Observability by others relates to social norms, similar to TPB and UTAUT. In diffusion of radical innovation, observability by others is frequently associated with a social identity, i.e., "do I want to transmit my identity as being innovative." Identity is one of the drivers of the radical changes in the U.S. beer market with the emergence of microbreweries (Rao, 2009; Verhaal, Khessina, \& Dobrev, 2015), or in reducing the attitudebehavioral gap in sustainable consumption (Van Dam \& Fischer, 2015).

Despite the identification of laggards and innovators in the diffusion of innovations literature, it is infamously difficult to characterize these consumers a priori. Consumers who are innovators for one technology may be laggards for another. Therefore it is hard to distinguish the adopter types based on demographic or psychographic profiles.

However, some personality characteristics may indicate systematic differences in innovation uptake between individuals. Perhaps the most frequently mentioned personality trait in the acceptance of new foods is food neophobia (Pliner \& Hobden, 1992). Food neophobia is a personality trait where people consistently favor known foods and are unwilling to adopt new foods. Food neophobia is shown to be an essential predictor for adopting foreign foods, and also predicts positive response to novel foods (Barrena \& Sánchez, 2013; Siegrist, 2008), new health products (Schickenberg, Van Assema, Brug, \& De Vries, 2008) and new protein sources such as insects 
(Hartmann \& Siegrist, 2016; Tan, Fischer, van Trijp, \& Stieger, 2016; Verbeke, 2015). The character trait of food neophobia has been further specified as food technology neophobia, which is the dislike to use new technologies to create foods (Cox \& Evans, 2008), which does not focus on new foods alone but also includes an aversion to (new) processing technologies. Classification of consumers on food neophobia may help innovators to assess who in society may reject what food innovations (Henriques, King, \& Meiselman, 2009). We should probably accept that extremely neophobic people may not accept any innovation. At least identifying how many and what kind of people may object can help prioritize further innovation. Other personality characteristics influence response to innovations. For example, variety seeking (e.g., Van Trijp, 1994) with people who consistently look for variety in their foods probably being more positive about innovations. Personal value orientations (e.g., Schwartz, 1994) can also influence innovation opinions, with people who have strong conservative values (tradition, security, conformity) more likely to be opposed to innovations, while those scoring high on openness to change (stimulation, self-direction, hedonism) more likely to support innovations. Evidence of the effect of such values on general consumer innovativeness general showed moderate to small effect sizes (Steenkamp, Ter Hofstede, \& Wedel, 1999). The influence of values on innovative choice has been further taken up in consumer decisions to engage in eco-innovations (Jansson, Marell, \& Nordlund, 2010), including the adoption of more radical innovations such as electronic cars (Barbarossa, De Pelsmacker, \& Moons, 2017).

\subsection{Radical food innovations today - societal issues}

So far, we have introduced some generic points of view on consumers in the early 2020 and theoretical models that can shed light on the adoption of disruptive innovations in food products, food production, and food supply chain management.

\subsubsection{Novel protein sources}

One radical ongoing innovation involves the introduction of novel foods and ingredients. Most notably we see a consumer and societal trend toward more demand for high-quality proteins in asking for foods with specific, functional, health benefits (Martins, Morales, Barros, \& Ferreira, 2017), and the notion that the current, mostly animal-based, production of proteins cannot be sustainable (Aiking, 2011). This latter realization has instigated the search for alternative protein sources, which includes the introduction of plant-based meat analogs (Hoek, van Boekel, Voordouw, \& Luning, 2011; Van Loo, Caputo, \& Lusk, 2020), insects (Van Huis et al., 2013), cultured meat (van der Weele \& Tramper, 2014), algae (Ścieszka \& Klewicka, 2019), duckweed (de Beukelaar, Zeinstra, Mes, \& Fischer, 2019), and legumes. 
From a consumer point of view, perhaps the most radical change has been that meat is no longer seen as a necessary daily part of the meal. The rise of flexitarianism (Dagevos, 2015) and low meat diets (de Gavelle et al., 2019) have influenced the societal position that a meal without meat is only half a meal. The idea of what a complete meal is and should be is being redefined in society. In line with this development, several national dietary guidelines (e.g., Sweden) and nonofficial guidelines (e.g., LiveWell) call to moderate or even limit meat consumption, especially consumption of red and processed meat (Gonzalez Fischer \& Garnett, 2016).

Innovative protein sources themselves also hold radical, innovative elements for society. By far, the most impactful has been the increasing popularity of plant-based meat analogs. Meat analogs are plant-based meat products created in such a way to mimic original meat in preparation and taste as much as possible. This fact allows consumers to replace animal proteins with alternatives without adjusting behavior. Brands such as Beyond Meat, the Vegetarian Butcher (Ingenbleek \& Zhao, 2019) and the Impossible Burger (Heffernan, 2017) create products that look like the originals. In the case of the impossible burger it even contains plant-based juice similar to those in "real" burgers. Impossible Whopper even became part of the Burger King menu across the USA in 2019. The disruptive element in this innovation may lie not so much on the consumer side but in the supply, where plant-based analogs may threaten the current business models of meat processing companies (Keefe, 2018). To deal with such changes, companies are investing in meat alternatives, with Unilever buying the Vegetarian Butcher in 2018 (Tziva, Negro, Kalfagianni, \& Hekkert, 2019) and gaining the European Burger King contract for plant-based burgers in 2019. ${ }^{1}$ Dutch-based meat processor Vion converted one of its beef processing plants into a plant-based site (Fortune, 2019). With the trend of plant-based meat alternatives, there is an ongoing debate to what extent using meat-like names (e.g., burger, schnitzel) for plantbased products will remain legally allowed under European and member state laws (Seehafer \& Bartels, 2019). In 2017, following complaints by the dairy industry, the EU regulated that dairy words like "milk," "cheese," "butter," "yogurt," and "cream" were banned for use by nondairy products, and this inspired the meat industry for its cases. This observation may be not so clear cut, as even for dairy, that has a limited number of names, exemptions were made for long-established products such as cacao butter, coconut milk, and peanut butter. In the USA several states no longer allow the use of "meaty" words for products not produced by raising livestock (Watson, 2019) while Seehafer and Bartels (2019) argue that customary use of meat-like names (such as burger) will remain allowed in the EU, as well as other naming strategies as long as

1. The red juice (a heme protein: leghemoglobin) of the impossible burger was created with genetically modified yeast not approved for the EU market; hence, the EU contract could not be granted to Impossible Foods. 
consumers are not misled by the product names. Of notice is, that at the time of writing (early 2020), the demand of plant-based meat analogs had increased to a level where shortages of processed soy and other legume proteins, required for the manufacturing of some of these products started to limit the market growth (Zhang et al., 2020). This shows that uptake of innovation may have disruptive effects further along in the production chain.

Cultured meat, in vitro meat, synthetic meat, lab-grown meat, clean meat, fake meat, animal-free meat (probably known under several other names as well), is another product that aims to mimic meat. Cultured meat is produced by growing meat substitutes from actual animal stem cells (Post, 2012). However, cultured meat has run into some challenges. In order to be a relevant, sustainable meat alternative, the growth medium needs to shift from bovine serum to growing medium that does not need such serum. While the development up until 2020 has been promising, nonanimal growth media remained inferior to those containing serum (Kolkmann, Post, Rutjens, van Essen, \& Moutsatsou, 2019). Another issue is the legal status of cultured meat. In Europe, it is considered a novel food which requires extensive testing before consumption is allowed (Seehafer \& Bartels, 2019). Also, while the cost of cultured meat has come down dramatically since its introduction as a $€ 250,000$ hamburger in 2013 , in 2019 , costs were still at least $€ 200$ per kilo (Purdy, 2019). It will still be a distant future where every village has its cultured meat plant (van der Weele \& Tramper, 2014), or where consumers grow their meat in their bio processor on the kitchen counter. From a consumer perspective, cultured meat seems desirable (Bryant \& Barnett, 2018; Verbeke, Sans, \& Van Loo, 2015; Wilks \& Phillips, 2017). However, consumers show a tough time in considering it as either meat or meat substitute (Bekker, Fischer, Tobi, \& van Trijp, 2017; Bekker, Tobi, \& Fischer, 2017). The problem consumers have with fitting in cultured meat into their view on meat suggests that adoption of cultured meat may require a (partial) redefinition of what meat is.

Another new protein type in the Western countries that has received much attention is that of eating insects. Hailed initially as a very promising meat replacer (e.g., Van Huis et al., 2013), insect-eating by humans has shown to be somewhat less prominent than hoped for. This is mainly due to western consumers exhibiting neophobia (Verbeke, 2015) or even disgust response when confronted with insects (Hartmann, Shi, Giusto, \& Siegrist, 2015), especially when recognizable insects are mixed with existing foodstuffs (Hartmann \& Siegrist, 2016). It is not only this initial dislike that consumers have to overcome. When comparing insect-eating between countries where insect-eating is part of the local cuisine, it becomes clear that consumers from these countries consider specific insects in the context of specific recipes, contribution to dishes and preparation methods (Tan et al., 2015) and show a more balanced view on specific insects compared to western populations (Hartmann et al., 2015). People from a culture where insect-eating is uncommon to have problems even recognizing insects as food (Tan et al., 2015), 
and have difficulties imagining how to prepare them (Tan et al., 2016). Recognition of insects as food seemed to be largely insect species-specific rather than culture-specific. Insects unknown food in insect-consuming cultures used to insect consumption were also not recognized as foodstuffs (Tan et al., 2016), while there is some evidence that those exposed to insect tastings in a culture without insects in their cuisine start to recognize specific insect species as edible (Fischer \& Steenbekkers, 2018). Many of the studies on consumer acceptance of eating insects focus on willingness to try (once), but it is, in the end, the repeated consumption that would make this innovation successful, and willingness to repeatedly use insects in food seems low (Tan et al., 2016). Early introductions of insect products in the supermarket have largely failed arguably because of the high price, inferior taste, and the difficulty fitting them into existing routines (House, 2016), as well as the placement among vegetarian products. All these factors may have contributed to a "passive rejection" where people may have been willing to try but were not ready to include it in their diets. These new burgers with insects have long been withdrawn from retail, showing that ignoring changes consumers have to make in adopting an innovative product in their daily life is not trivial.

A similar issue may occur when trying to bring aquatic crops such as algae and duckweed products in the market. Initial consumer research on acceptance of duckweed as human food suggests that use in salads or applications where greenery is expected as a condiment would make acceptance much more likely than heavily processed applications (de Beukelaar et al., 2019). Algae are an exciting class of innovative protein sources. Macroalgae such as seaweed are associated with specific cuisines, most notably sushi (Birch, Skallerud, \& Paul, 2019), and maybe introduced as such. Microalgae, such as spirulina, may enter the market as functional food ingredients (Grahl, Strack, Weinrich, \& Mörlein, 2018), particularly in food drinks, or for specific groups of vulnerable people (Santos, Freitas, Moreira, Zanfonato, \& Costa, 2016). Spirulina as high protein supplements is now becoming more common among specific groups with high motivation to gain the functional aspects (sporters, vegetarians) or those interested in food innovation in general (Moons, Barbarossa, \& De Pelsmacker, 2018). However, in the light that only a minority of the population reports using functional foods regularly (Sparke \& Menrad, 2009), it remains to be seen to what extent these functional food applications of spirulina are a start of further diffusion of spirulina supplements to the broader food market, or whether (in terms of diffusion of innovations) the entire markets consists of these highly motivated niches.

Herein, we identified a number of relevant issues to end-users, which shows that a genuinely radical approach inputting new food products on the market often runs into trouble (e.g., insect foods). We also argue introductions that allow consumers to evolve toward a new food consumption pattern (e.g., meat analogs in plant-based meat substitutes) are more likely to be successful. For more radical innovations to be successful, it seems, therefore, that a more incremental rather than radical or disruptive innovation approach is the best way to get in the market. 


\subsubsection{High tech and precision agriculture}

While mechanized agriculture is now commonplace, fully automated and precision agriculture is emerging. This has substantial effects on how farms operate and may impact the societal view on farming. An example that is being adopted across Europe and Northern America is that of Automatic Milking Systems or Robot Milkers (Butler, Holloway, \& Bear, 2012). Such systems can milk dairy cattle without (real-time) involvement of the farmer. The cow moves into the robot system whenever she wants to be milked, is recognized by the system, and receives tailored feed while being milked. An automatic analysis of milk quality is then used to adjust feed composition for the next milking session. The role of the farmer has become that of a controller who has to check the robot generated data to ensure their cows are healthy and receive the best possible feed. There could, however, be a catch to this approach, as continuing automatization of animal husbandry could be considered as further objectifying the animals by removing the remaining contact with a caring human (cf. Bos, Bovenkerk, Feindt, \& Van Dam, 2018). In the case of the milking robots, these initial concerns were incorporated in the final development of the Robot Milker of a Dutch company.

By ensuring the cow chooses when to enter the robot, the autonomy of the cow was established as a more critical increase in animal welfare than the reduced contact with the farmer was detrimental for animal welfare (Driessen \& Heutinck, 2015). Society is readily accepting this more natural behavior as desirable even if facilitated by high-tech, and hence, assumedly nonnatural (Rozin, 2005) robot milking. This early example of mechanized agriculture is only the beginning, however. More all-encompassing automation is expected in agriculture. Current studies are ongoing to develop fully autonomous greenhouses (Ko, Ryuh, Kim, Suprem, \& Mahalik, 2014), drone surveillance (Mogili \& Deepak, 2018), robot weeders (Hussmann, Knoll, Meissner, \& Holtorf, 2019) and fully automated harvesters that can find their way across fields (Rahman, Ishii, \& Noguchi, 2019). All these development will generate big data that has to be processed and interpreted to maximize the benefits of these systems and to integrate data streams from different systems. These studies have focused to a large extent to radical changes in the production chain, most dominantly the position of the farmer that is rapidly changing from manual laborer to a process operator (Bramley \& Ouzman, 2019). Given the amount and complexity of the data, the farmer needs the support of data companies for the advanced analyses needed. This fact raises the issue of data ownership, i.e., to what extent does the farmer keep a say over their data, and to what extent can the data company use it freely for their profit (Fraser, 2019); a discussion reminiscent of the data ownership concerns that emerged with (on the face of it) free of charge social media platforms (Veletsianos, Johnson, \& Belikov, 2019).

Similarly, drone surveillance raises privacy concerns among people living within the range of such drone surveillance (Ahirwar, Swarnkar, Bhukya, \& Namwade, 2019; Oltvoort, de Vries, van Rompay, \& Rosen, 2019). Given the 
relatively small scale agriculture in Europe, this almost certainly will be an issue for agricultural drone surveillance. Similar analogies can be drawn between fully automated harvester and self-driving cars (by early 2020 neither being allowed on public roads) (Suganuma, 2019). A fully automated harvester while contained within a field may be acceptable, although the killing of wildlife may raise some protests. Strong guarantees would be needed that such harvesters cannot leave the designated field and that while traveling to and from the fields, it will ensure the safety of other road users (Borenstein, Herkert, \& Miller, 2019). Again, the relatively small scale of European agricultural plots is likely to make these issues salient in that continent.

Precision agriculture is a radical innovation that will have a significant impact on primary food producers (farmers) but may also raise some societal concerns. These are most likely due to an aversion against increasingly high-tech agriculture leading to (further) objectivation of animals and the deprecation of rural areas as a naturally perceived environment. Also, privacy concerns and bystander safety need to be dealt with in developing fully automated systems.

\subsubsection{Smart in-home appliances}

The Internet was initially developed for the transfer of data. To date, most of the Internet still is about transferring data, making online orders, engaging in games, audio or video streams, social media, or otherwise communicating with peers or stakeholders. Increasingly the Internet is also becoming integrated into physical products. Doorbells, alarm systems, smart television, and many other in-home appliances now communicate with the Internet, transfer data between each other and external data analysis services. This Internet of things (IoT) may also start affecting food consumption in society. A long-standing promise has been the smart fridge, which in theory, should be able to provide recipes, keep track of stock, and prompt users on their smartphone to replenish specific products, keep track of use-by dates, and provide nutritional advice based on currently stocked foods. Consumers perceive the smart fridge functionality as moderately useful and particularly like keeping track of use-by dates and nutritional advice (Rothensee, 2008, pp. 123-139). The function of keeping track of use-by dates is (for about 20 years already) a technological challenge that requires food to communicate use-by dates to the fridge. This can either be by unique barcodes that report use-by dates (Keluskar, no date) or Radio-frequency identification (RFID) that transmit these use-by dates (Ferrero, Vakili, Giusto, Guerrera, \& Randazzo, 2019).

Given that neither is the default in the food market and given the low margins in food retail, such expensive product-specific tags are unlikely to be implemented in retail any time soon. Therefore, at this moment in time, the only way to have smart fridges keeping track of use-by dates is by having consumers attach them to their groceries before storing. Individually labeling 
each product with smart-fridge readable use-by dates will add a considerable burden on consumers for each shopping trip. Not surprisingly, the current generations of high-end smart fridges do not keep track of use-by dates. Some of the higher end fridges contain cameras that allow the user to visually see the inside of the fridge, and thus, track contents while shopping, assuming that the static camera has an unobstructed view on all relevant items.

Another technology that through information technology could change how consumers deal with food stocks and production at home is 3D printing of food. $3 \mathrm{D}$ food printing is a technique in which a food product is constructed in layers from cartridges with preprocessed contents. In theory, a 3D printer could create many shapes of foods with a range of tastes by mixing essential ingredients. In that way, the 3D food printer holds promises similar to the Star-Trek replicator we started this chapter with (Desai 2019). Imagine just having to purchase the compatible cartridge and download a recipe from the Internet, and awardwinning food appears in the domestic kitchen. In practice, the current state of the art is much more limited, and 3D food printing is mainly used for professional applications. 3D printing sees some applications in custom made sweets (mainly chocolate and sugar work, and some biscuit shapes). For these products, $3 \mathrm{D}$ printing allows the creation of complex or highly personalized shapes that cannot be made at all or not at any reasonable cost in other ways (Liu, Zhang, Bhandari, \& Wang, 2017). Another application of 3D printing is to support the appetite of the elderly who cannot eat solid foods. In the past, the solution was to provide these people with unappealing pureed foods, resulting in a reduced appetite. By creating more appealing shapes through $3 \mathrm{D}$ printing, the purees in the shapes of recognizable foodstuff, appetite, and with that quality of life of the elderly can be improved, while maintaining the softness of the puree (Liu et al., 2017). These applications are, however, far from the domestic kitchen. Costs are too high, 3D printing does not fit routine food preparation behaviors, and prefilled cartridges are not available while creating the fillings of cartridges in the domestic kitchen increases complexity and effort needed for food preparation rather than reducing it.

One issue that is evolving around the emergence of the Internet of things in general and in-home appliances specific is that of cybersecurity. This issue has recently moved high on the agenda for the Internet of things and needs considerable attention from developers of smart appliances and data services that collaborate with them (Guhr, Werth, Blacha, \& Breitner, 2020). So far, it seems that smart appliances have a much lower security level than, for example, computers. This poses several risks. First, through the weak protection of smart appliances, criminals may gain access to the home network. Second, and not unimportantly, mere access to the data streams from, e.g., the fridge to suppliers or smartphones may inform others about the exact contents of your fridge in real-time. This fact may sound trivial, but do you want burglars to be able to track when a fridge is not restocked for some time, which may indicate a holiday. Do you want your health insurance or employer 
to have access to your fridge contents, allowing them to keep track of the health of your diet or the amounts of, e.g., beers consumed in your household?

Internet of things and smart hardware has the potential for radical changes in domestic food usage. The current versions of these appliances do, however, only offer limited functionality of this kind. The security of these appliances, their data streams, and the privacy sensitivity of the associated data are only just being incorporated into the designs. There seems to be much promise, but actual adoption may take some time.

\subsubsection{Transparency in food supply chain through traceability by blockchain}

New data-driven technologies are being applied in the food sector, such as blockchain technology, allowing for storage and sharing of data along the food supply chain in a transparent and unmodifiable way. While a traditional database is often owned by one organization or person and susceptible to manipulation, blockchain technology allows the sharing of a decentralized database across a whole network where everyone can contribute, and data cannot be altered. While blockchain was initially mainly associated with financial services, the blockchain's decentralized database for sharing, storing, and securing data offers innovative food quality traceability and transparency systems to the food supply chain, in particular in tracking individual products and their ingredients to their specific origins. The traceability information can relate to any of the six traceability elements identified by Opara (2003) in Karlsen, Dreyer, Olsen, and Elvevoll (2013) (product, process, genetic, input, disease/pest, and measurement traceability). For example, the provider adds information about the crops, the producer on pesticide use, fertilizer use, and other information about the crop cultivation, the distributor on details on shipping, storage conditions, and the retailer add details on expiration dates. The consumer can then access all of the information for the individual products, for example, through scanning a QR (quick response) code.

Several useful foods tracing applications along the supply chain include (1) fast and specific responses to foodborne illness outbreaks, (2) food integrity and authenticity, and avoiding food fraud, (3) building consumer trust in the food supply.

Fast and specific responses to foodborne illness outbreaks. Blockchain technology may contribute to a transformation in food safety prevention. In Europe, every year, over 23 million people suffer from a foodborne illness from eating contaminated food (WHO, 2017), mainly caused by Norovirus, Campylobacter, and Salmonella poisoning. In order to reduce foodborne illnesses, it is key to act quickly when food contamination outbreaks occur. When using the existing food tracing system, it can take some time to identify the specific source of the outbreak, which can cause further illnesses and often leads to overly broad product recalls resulting in unnecessarily large amounts 
of food being lost. For example, during an E. coli outbreak linked to Romaine lettuce, the U.S. CDC (2018) (Center for Disease Control and Prevention) warned U.S. consumers not to eat any Romaine lettuce and restaurants and retailers not to sell it. This resulted in a huge loss of Romaine lettuce. With adequate recordkeeping and data sharing, the source of food contaminations could be located quicker, leading to improved public safety, and less food wasted by retailers and farmers. In 2017, a group of large food producers (e.g., Nestlé, Unilever, Tyson) and retailers (e.g., Walmart, Kroger) started to integrate IBM's blockchain Food Trust into their supply chain to increase food traceability, and increasingly more fast-moving consumer goods (FMCG) companies are joining. One of the largest retailers (e.g., Walmart Inc.) requires their suppliers of lettuce, spinach, and other greens, as well as the suppliers of these suppliers (farmers, logistics companies, and business partners) to join the food-tracking blockchain system (Nash, 2018). This led to increased product traceability and a targeted recall. By supporting food safety during a recall through its blockchain records, it thus also creates consumer trust (Galvez, Mejuto, \& Simal-Gandara, 2018).

Food integrity and authenticity - preventing food fraud. Blockchain applications in the food supply chain may help to fight food fraud. Blockchain technology provides an unchangeable, transparent, and traceable record along the food chain. As a result, blockchain systems can help to assure food integrity and help tackle problems such as fraud, counterfeit, and mislabeling along the food supply chain. Thus blockchain technology can play a role in managing the reported loss of public and consumer confidence in food production and the food industry. In the blockchain system, all information on the product can be stored from the start of the supply chain to the retail such as pesticides use, details about the livestock, feed, and importantly once stored cannot be changed. Hence, in a food supply chain controlled with blockchain technology, fraud and contamination can be detected more quickly, and even more, the source of the fraud and contamination can easily be identified. This may help to prevent food fraud regarding specific food certifications, (accidental) misdescribing and mislabeling, and adulteration such as the 2013 horse meat scandal, where substantial quantities of horse meat were entered into beef production chains. If the origin of the adulterated meat had been stored using blockchain registers, the companies who were first to enter these horse meats into the supply chain could likely have been identified much faster.

Building consumer trust in food supply from farm to fork. Blockchain systems allow food businesses to store all data from farm to fork in a reliable and transparent system, resulting in radical innovations in the way food chains are managed. If companies make this information available to consumers, this may help to build a trust relationship with consumers (Xiong, Dalhaus, Wang, \& Huang, 2020). By transparently sharing information about the individual product, guaranteed by blockchain registration, companies can build a better reputation for their company and products (Xiong et al., 2020). Already, some 
producers or retailers provide $\mathrm{QR}$ codes that consumers can scan to access product traceability information across the entire supply chain. This includes information about the route the product has taken from the farm to the shelves. For consumers, blockchain technology ensures reliability and transparency of such information on food production and addresses their potential concern about food safety and food quality. There is some evidence that a food traceability system can facilitate consumer confidence that strict requirements for food labeling claims are met. For example, Charlebois and Haratifar (2015) reported that Canadian consumers would appreciate a traceability system for organic milk. While $4 \%$ of consumers indicate to always purchase organic milk under current regulation without a traceability system for consumers, $27 \%$ would always and $53 \%$ would consider purchasing traceable organic milk (Charlebois \& Haratifar, 2015). Consumers' preferences for identifiable information also differs based on the food category (Liu, Li, Steele, \& Fang, 2018). Sander, Semeijn, and Mahr (2018) reported a positive relationship between the presence of the blockchain traceability for meat and consumers' quality perception and purchase decision. Several studies indicate that Chinese consumers are willing to pay a premium for traceable food (Jin, Zhang, \& Xu, 2017; Liu, Gao, Nayga, Snell, \& Ma, 2019; Zhang, Bai, \& Wahl, 2012); there are, however, no studies whether this also holds for other countries. So far, no research evaluated real consumers' purchase behavior or nonhypothetical willingness to pay for traceable food products by observation or auction experiments. For traceability for fish, consumers have positive attitudes about traceability data and indicate that they mainly want to use it to verify the origin and producer claims (Rodriguez-Salvador \& Dopico, 2020).

Food chain actors have high hopes blockchains data will be read, and thus, increase consumer and societal confidence in their productions. Whether this reassurance of food quality and safety is valued and will be read by consumers remains uncertain. Liu et al. (2019) reported that only $1.2 \%$ of all consumers accessed the information provided by a $\mathrm{QR}$ code on a food package, although more than half of the participants accessed the $\mathrm{QR}$ code when provided with a smartphone with QR scanning software preinstalled. Liu et al. (2019) argue that convenient and fast access is essential for consumers to retrieve information. Studying the consumer acceptance of a QR code for food traceability information using the TAM model, Kim and Woo (2016) similarly found that the consumers' attitude toward using the QR code and subsequent scan intention is affected by the expected information provided, as well as the perceived usefulness, and perceived ease of use.

Blockchain is a promising technology for the food supply sector, but it faces some challenges for the blockchain to be implemented along the food supply chain (Kamilaris, Fonts, \& Prenafeta-Boldu, 2019). It can only be successful when all actors along the supply chain participate. At this moment in time, however, many food industry companies still use stand-alone record keeping, and no history of shared registers of product lines, such as blockchain, exists in the food sector (Aaron, 2018). Setting up the infrastructure for blockchain and 
ensuring commitment to the system for all actors is, therefore, an important hurdle to the implementation of blockchain to ensure transparency. While for consumers, the innovation to access product history may not seem very large, the changes within the supply required to ensure this are disruptive.

\subsubsection{Personalized dietary advice}

The dietary habits in the developed world are leading to a high prevalence of noncommunicable diseases such as obesity, type 2 diabetes, and cardiovascular diseases due to the high consumption of saturated fat, added sugar, and salt and insufficient fruit and vegetables (WHO, 2018). Consequently, there is a need to change toward a healthier dietary pattern. Most free dietary advice is population-level, or at least population subgroup level recommendations, and follow a one-size-fits-all approach, such as "eat at least $200 \mathrm{~g}$ of vegetables daily" and "limit salt intake to $6 \mathrm{~g}$ daily" (WHO, 2015). Population-level dietary advice does not effectively address individual needs. Instead, a personalized nutritional approach specifies dietary recommendations tailored to the individual and has the potential to be more effective in changing dietary behavior (Celis-Morales et al., 2017; Celis-Morales, Lara, \& Mathers, 2015; Ferguson et al., 2016). Personalized dietary advice is tailored to one's specific individual needs based on genotype or physiological characteristics, phenotype, and current nutritional status (Gibney \& Walsh, 2013; Livingstone et al., 2016). In addition, an individual's lifestyle and personal preferences may be considered to formulate personalized dietary advice by personalized nutrition services. While to date, there is no consensus on a definition of personalized nutrition, experts agree that "the goal of personalized nutrition is to advance human health and wellbeing by tailoring nutrition recommendations and interventions to individuals or groups of individuals with similar traits" (Bush et al., 2020, p. 5).

There are three important stages in the information exchange process for personalized nutrition services (Berezowska et al., 2014 Fig. 9.1), contributing to the consumer acceptance of personalized nutrition services. First, consumers need to be willing to disclose the requested personal, potentially sensitive

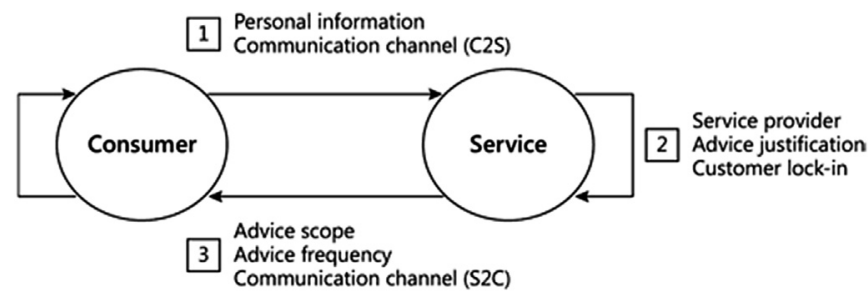

FIGURE 9.1 Schematic overview of the personalized nutrition information exchange process and its attributes. Berezowska, A., Fischer, A. R. H., Ronteltap, A., Kuznesof, S., Macready, A., Fallaize, R., et al. (2014). From: Understanding consumer evaluations of personalised nutrition services in terms of the privacy calculus: A qualitative study. Public Health Genomics, 17(3), $127-140$. 
information to the service provider through the chosen communication channel. Second, the personalized nutrition service provider will develop personalized dietary advice, followed by communicating the advice to the consumer, where the consumer needs to understand and trust the given advice. The consumer adoption of the advice will depend on the trade-off between the perceived privacy risk and the perceived personal benefit (Berezowska et al., 2014; Berezowska, Fischer, Ronteltap, Van der Lans, \& Van Trijp, 2015).

Consumer acceptance of personalized advice may differ depending on the specific personalized nutrition service design attributes, and thus, the personalized nutrition design attributes need to be carefully selected. A wide range of personalized nutritional services exists (Ronteltap, Van Trijp, Berezowska, \& Goossens, 2013). Specifically, the personalized nutrition service approaches differ in terms of the type of personal information disclosed (e.g., dietary intake data, phenotypic information, genotypic information, lifestyle), the type of business model and service provider (e.g., employer, dietitian, fitness club, consultant), target group, and communication channels (e.g., personal contact, app, Website, e-mail) (Berezowska et al., 2014, 2015; Ronteltap et al., 2013). The details of the advice itself will have an impact on consumer acceptance, and this advice can differ in term of the type of personalized offer or advice scope (e.g., personal diet plan, personal coach, personalized shopping list, whether or not the nutritional advice is combined with advice on physical activity), advice frequency, the message framing, as well as the information presentation (Berezowska et al., 2014, 2015; Nguyen et al., 2017; Ronteltap et al., 2013). The consumer response and willingness to adopt varies based on the personalized nutrition service design attributes and the implications of these design attributes for the information exchange process. For example, Berezowska et al. (2014) reported that consumers prefer an expert or dietitian to be the personalized nutrition service provider rather than the government or the employer.

The implemented personalized nutrition service attributes influence intention to adopt as they relate to the perceived personalized benefit, i.e., the degree to which the advice is personally relevant, and the perceived risk of privacy loss as personal and perhaps sensitive health information is shared. A highly relevant and personalized recommendation is more likely to lead to a perceived personal benefit but may also require the sharing of sensitive information, leading to perceived privacy risk. Berezowska et al. (2014) argue that consumers trade-off the perceived personal benefit and the perceived privacy risk called the risk-benefit calculus, which is related to the intention to adopt personalized advice. To encourage consumer adoption, it essential to reduce the perceived privacy risk and increase perceived personal benefit of personalized nutritional advice (Berezowska et al., 2014; Reinders, Bouwman, van den Puttelaar, \& Verain, 2020). Berezowska et al. (2015) further suggested to clearly communicate the personal benefit of personalized advice over nonpersonalized advice to enhance its effectiveness. The perceived privacy risk perceptions should be minimized by transparently sharing how the personal data 
will be protected (Berezowska et al., 2015; Reinders et al., 2020). However, the intention to adopt personalized advice depends on more than the trade-off between the risk and benefits perception of the information disclosure.

Personality traits, knowledge, and values should be taken into account when developing the personalized advice and how to communicate it to optimize its effectiveness (Ronteltap, van Trijp, Renes, \& Frewer, 2007). For example, Berezowska, Fischer, \& van Trijp (2017) suggest that the personalized dietary recommendation takes one's level of self-determination into account. For individuals with high levels of autonomous motivation, i.e., the decision to eat healthily is self-determined, one should focus on the benefits, while for individuals with high levels of controlled motivation, risk-reduction properties of such a service should be emphasized. Ambivalent feelings, which occur when one has both negative and positive evaluations, may negatively impact the intention to adopt the personalized nutrition advice, so directly countering risks with more benefits, resulting in higher risk and benefit perception, and hence, higher ambivalence may not be the way forward (Reinders et al., 2020). Consumers' concerns need to be taken seriously, and the advice should minimize potential ambivalent feelings.

\subsection{Digital food purchases and food ordering}

Digital technologies are transforming the food shopping landscape. Recently food online to off-line $(\mathrm{O} 2 \mathrm{O})$ e-commerce is growing with increasingly prevalent online food shopping and online meal ordering platforms (Roh \& Park, 2019). Consumers can thus shop online for (1) groceries, which in the content of goods is closely related to a traditional shopping trip, (2) meal kits delivered to their homes which provides conveniently portioned food allowing faster preparation (3) prepared, ready to eat, meals. These different online food delivery services cater to consumer demand for convenient food purchases in different ways:

(1) Online grocery shopping and delivery. E-commerce and online shopping have boomed in the last two decades, allowing them to have any products at our fingertips without having to leave the house, with only a matter of a few clicks. While online shopping for groceries is not yet as common compared with the other product categories such as clothes and travel (Eurostat, 2020), it is proliferating. Research by FMI and Nielsen (2018) predicted that $70 \%$ of U.S. consumers would be purchasing groceries online by 2024, illustrating the "rising digital grocery landscape. " In Europe, the adoption of online grocery shopping sometimes referred to as e-groceries, is also rising quickly. In $2019,27 \%$ of the e-shoppers in the EU-28 purchased food online (Eurostat, 2020). This fact is amounting to substantial monetary revenue, with recent research predicting that 10 leading global online grocery market will account for $€ 200$ billion in sales. 
The most important underlying motivations to shopping for e-groceries are convenience (e.g., reduction in effort, ordering at any moment of the day at any place, access to a wider product assortment), saving time (Seitz, Pokrivčák, Tóth, \& Plevný, 2017), and the often more favorable prices (IRI, 2019). Online food shopping differs from online shopping for other products (Mortimer, Fazal e Hasan, Andrews, \& Martin, 2016) as many food products are perishable, and consumers value freshness of food products. This is also reflected in the barriers to online food shopping, such as lack of trust and lack of control and concern about product quality since you cannot select your own products. While online food shopping faces some challenges, consumers are increasingly finding their way to shop for groceries away from the brickand-mortar stores. New companies or companies initially not involved in food sales enter the e-grocery market (e.g., AmazonFresh, AmazonPantry, Picnic, Instacart). At the same time, traditional brickand-mortar grocery chains have now created online grocery shopping environments, and allow for both home delivery, as well as pick-up points ("click-and-collect" options) where consumers collect their order.

More so than in other sales channels, many consumers were reluctant to change their habitual grocery shopping behavior and were not ready to leave their trusted brick and mortar grocery shop, in part because they were unfamiliar with shopping online for food. There are, however, indications this may have changed during the 2020 COVID-19 outbreak. With rising concerns to enter physical stores due to the risk for contamination and the government lockdown policies, many consumers adopted online grocery shopping resulting in a surge in e-groceries. This caused, both in the U.S. and Europe, large delivery waiting times, and consumers sometimes even being placed on waiting lists. Grocery stores needed to expand their online operations and had to look for additional employees to assist with the rapid expansion of online orders. While we do not know what will happen once the food retail and the society have recovered from this pandemic, many sources are predicting that this pandemic may have catalyzed the digital transformation, including for the transition to online grocery shopping and grocery delivery as consumers may have become more familiar with online groceries and may continue to shop online for groceries after the pandemic (Goddard, 2020; Hobbs, 2020).

(2) Subscription meal boxes. Meal kits were originally offered as subscription meal boxes (e.g., Blue Apron, Marley Spoon, HelloFresh) and include recipe cards and preportioned ingredients to prepare home-cooked meals. Consumers subscribe to meal box plans to save time but still experience a home-cooked meal with the help of the easy recipes on recipe cards. The meal boxes thus save time and reduce the mental and physical efforts since consumers do 
not have to shop for groceries nor have to engage in meal planning (Hill \& Maddock, 2019; Khan \& Sowards, 2018). Meal kits are seen as a convenient food, which lessens the dinner related tasks, but still gives consumers the feeling of "cooking from scratch" (Hertz \& Halkier, 2017). This compares to traditional convenience foods which are often ready-to-eat meals, giving consumers the feeling of guilt for not cooking a meal from catch (Costa, Schoolmeester, Dekker, \& Jongen, 2007). While delivery of meal kits may offer time-saving, it may lack some flexibility as consumers precommit to the number of meal kits each week, which may not allow last-minute change of plans. This lack of flexibility may prevent consumers from remaining a meal kit subscriber, and meal kit providers are developing strategies to deal with this (e.g., a pause option to delay delivery). Meal kits have impacted food retail, which now also offers meal kits in their brick and mortar stores.

(3). Meal delivery services. While in the past, meal delivery was often a service provided by few restaurants, most notably pizza chains, with Pizza Hut being the first to allow online ordering, it has now expanded tremendously. Digital meal ordering is becoming increasingly prevalent, and the global online food delivery market was estimated at $\$ 35$ billion and expected to rise to $\$ 365$ billion by 2030 (Business Insider, 2018). Digital meal orders can be placed on a mobile app, Website, or with a text message. More recently, companies specialized in meal delivery, the so-called third-party meal delivery services, have emerged that offer a restaurant-to-consumer platform, allowing restaurants without their own preexisting delivery service to home-deliver. This online-to-offline $(\mathrm{O} 2 \mathrm{O})$ meal delivery market is multiplying, and many players are active in this market (e.g., Uber Eats, Takeaway, Just Eat, Deliveroo, GrubHub) currently competing for a market share in the food delivery space. Ray, Dhir, Bala, and Kaur (2019) reported that convenience, societal pressure, customer experience, delivery experience, search of restaurants, quality control, listing, and ease-of-use all influence the consumers' use of food delivery apps, with performance expectancy being significant for the intention to use online food delivery systems (Gunden, Morosan, \& DeFranco, 2020). Digital meal ordering may impact consumer diets, for better or worse. Some academics are advocating to study how to incorporate behavioral change techniques into the digital meal ordering platform to assist consumers in choosing healthier meal options (Stephens, Miller, \& Militello, 2020).

These three $\mathrm{O} 2 \mathrm{O}$ food delivery services target convenience-seeking consumers, and convenience-oriented consumers are more likely to adopt such delivery services (Roh \& Park, 2019). Nevertheless, some concerns remain as consumers with a higher moral obligation are more hesitant to adopt online food services (Roh \& Park, 2019). 
While still developing, online groceries and food ordering collect customer data and through its flexible online environment could be used to create tailored product offerings, personalized suggestions to help consumers make healthier dietary decisions and apply targeted advertising. This fact may further change how consumers plan and purchase foods in the future, but may also lead to privacy concerns and reluctance with consumers associated with that.

\subsection{Radical food innovations and society - what next}

Considering the disruptions caused by current innovations in food science and technology, a few issues can be identified that will facilitate or hinder its societal acceptance.

The move toward a palette of sustainable protein sources to (partially) replace, and hence, reduce the sustainable impact of animal husbandry will not be as easy as sometimes thought. Across many studies, a general willingness to consider eating less meat, for trying alternatives, even less than apparent protein alternatives such as insects, or high tech produced cultured meat, is observed. However, when we look closer, we also realize this does not translate directly into a shift toward eating less meat. While flexitarian diets are now considered more "normal," people still consume about the same amount of meat. While people are willing to try insects once, they do not consider them relevant alternatives to meat in their regular diet. Duckweed foods that brought duckweed to the meal as a salad were most acceptable, but salads are not regular meat replacements in meals. Cultured meat, in particular, formed a puzzle to consumers as to whether it is meat or something else. This suggests that the disruptive element in these innovations is not as much in a deliberate willingness to try the new products, but more in a reluctance, or inability to change long-standing interpretations and patterns of the daily meal. Breaking such habits is, because of their unconscious nature, often more challenging than merely convincing consumers to try, and that they are willing to try shows an opening nonetheless.

The second group of disruptive innovations in food production revolves around the convergence of microelectronics, information technology, and food technology. While there may be less impact on actual food properties (except 3D printed foods), the idea that food production is even further industrialized in precision agriculture may upset some among the public. More importantly, there are ethical concerns around such high tech information applications. Who is responsible for autonomous robots if accidents occur? Who safeguards privacy around drone surveillance or even more importantly about the fridge contents kept by a smart fridge, shopping lists in digital marketing applications, and who controls the storage, interpretation of health profiles that may include DNA profiles in personalized nutrition services? These concerns have been changing the way we position ourselves about social media but are now also encroaching on food supply chain issues. Besides concerns, part of the solution may lie in information technology, however. Blockchain technology 
may make supply chains more transparent, and thus, present reassurance to the public. Mobile phones are now ever-present, and many new innovative portable biosensors to be linked with our personal devices are being developed. Together with the development of personalized self-learning algorithms, digital nutritional expert systems providing personalized nutritional advice are likely to exist soon (as outlined in more detail in Michel \& Burbidge, 2019) and may contribute to a reliable, robust food supply.

Food technologies related to resilient and robust supply chains have become even more urgent over the time we spent writing this chapter. When we started writing this chapter in early 2020, supply chains of food and medical supplies were assumed to be stable and sufficient if not abundant in developed countries. While we are finalizing this chapter only a few weeks later, hoarding had emptied supermarket food (and toilet paper) supplies, and essential medical supplies across the world became depleted. Important production sites have been offline for extended periods, and international travel has mostly stopped. The ripple effect showing the vulnerability of our highly optimized interdependent high tech production systems may trigger new ways in how we deal with food, food technology, and organizing supply chains and information streams around it. A food retail system based on a justin-time approach is efficient in regular times, but may cause many problems and is vulnerable during a crisis as we currently see during the COVID-19 pandemic. Currently, we can only see short-term problems arising in the food supply chain, and the long term effects on consumer demand and consumer perceptions are unknown. However, the pandemic's effects are radical and disruptive, with potentially lasting changes in food production and retail. In recovering from the pandemic, public opinions of innovations discussed in this book may rapidly change for the better or worse and may create a changed outlook on food production in general. While we do not precisely know how culture may change, we can nevertheless expect that general principles in which neophobia, diffusion of innovation, personal deliberations, and the impact of (sub) cultures on acceptance of disruptive innovations influence society will remain the same and will help us interpret what comes next.

\section{Acknowledgments}

The Dutch 4TU Federation supported the writing of this chapter through the Pride and Prejudice project.

\section{References}

Aaron, C. (2018). Romaine, blockchain, and the future of food safety. FSR Magazine.

Ahirwar, S., Swarnkar, R., Bhukya, S., \& Namwade, G. (2019). Application of drone in agriculture. International Journal Curr. Microbiological Applied Science, 8, 2500-2505.

Aiking, H. (2011). Future protein supply. Trends in Food Science \& Technology, 22(2), 112-120. https://doi.org/10.1016/j.tifs.2010.04.005 
Ajzen, I. (1991). The theory of planned behavior. Organizational Behavior and Human Decision Processes, 50(2), 179-211.

Askegaard, S., \& Brogård, D. (2016). 'Authentic food'and the double nature of branding. In The practice of the meal (pp. 39-54). Routledge.

Bagozzi, R. P. (2007). The legacy of the technology acceptance model and a proposal for a paradigm shift. Journal of the Association for Information Systems, 8(4), 244-254.

Barbarossa, C., De Pelsmacker, P., \& Moons, I. (2017). Personal values, green self-identity and electric car adoption. Ecological Economics, 140, 190-200. https://doi.org/10.1016/ j.ecolecon.2017.05.015

Barrena, R., \& Sánchez, M. (2013). Neophobia, personal consumer values and novel food acceptance. Food Quality and Preference, 27(1), 72-84.

Bass, F. M. (1969). A new product growth model for consumer durables. Management Science, 15(5), 215-227.

Bekker, G. A., Fischer, A. R. H., Tobi, H., \& van Trijp, H. C. M. (2017). Explicit and implicit attitude toward an emerging food technology: The case of cultured meat. Appetite, 108, 245-254. https://doi.org/10.1016/j.appet.2016.10.002

Bekker, G. A., Tobi, H., \& Fischer, A. R. H. (2017). Meet meat: An explorative study on meat and cultured meat as seen by Chinese, Ethiopians and Dutch. Appetite, 114, 82-92. https://doi.org/ 10.1016/j.appet.2017.03.009

Belasco, W. (2000). Future notes: The meal-in-a-pill.

Berezowska, A., Fischer, A. R. H., Ronteltap, A., Kuznesof, S., Macready, A., Fallaize, R., et al. (2014). Understanding consumer evaluations of personalised nutrition services in terms of the privacy calculus: A qualitative study. Public Health Genomics, 17(3), 127-140.

Berezowska, A., Fischer, A. R. H., Ronteltap, A., Van der Lans, I. A., \& Van Trijp, H. C. M. (2015). Consumer adoption of personalised nutrition services from the perspective of a riskbenefit trade-off. Genes and Nutrition, 10(6), 2-14.

Berezowska, A., Fischer, A. R. H., \& van Trijp, H. C. M. (2017). The moderating effect of motivation on health-related decision-making. Psychology and Health, 32(6), 665-685. https://doi.org/10.1080/08870446.2017.1293055

de Beukelaar, M. F. A., Zeinstra, G. G., Mes, J. J., \& Fischer, A. R. H. (2019). Duckweed as human food. The influence of meal context and information on duckweed acceptability of Dutch consumers. Food Quality and Preference, 71, 76-86. https://doi.org/10.1016/ j.foodqual.2018.06.005

Birch, D., Skallerud, K., \& Paul, N. A. (2019). Who are the future seaweed consumers in a western society? Insights from Australia. British Food Journal, 121(2), 603-615. https://doi.org/ 10.1108/BFJ-03-2018-0189

Borenstein, J., Herkert, J., \& Miller, K. W. (2019). Autonomous vehicles and the ethical tension between occupant and non-occupant safety. Computer Ethics-Philosophical Enquiry (CEPE) Proceedings, $2019(1), 6$.

Bos, J. M., Bovenkerk, B., Feindt, P. H., \& Van Dam, Y. K. (2018). The quantified animal: Precision livestock farming and the ethical implications of objectification. Food Ethics, 2(1), 77-92.

Bramley, R., \& Ouzman, J. (2019). Farmer attitudes to the use of sensors and automation in fertilizer decision-making: Nitrogen fertilization in the Australian grains sector. Precision Agriculture, 20(1), 157-175.

Bredahl, L. (2001). Determinants of consumer attitudes and purchase intentions with regard to genetically modified foods - results of a cross-national survey. Journal of Consumer Policy, 24(1), 23-61. 
Bruhn, C. M. (1995). Consumer attitudes and market response to irradiated food. Journal of Food Protection, 58, 175-181.

Bryant, C., \& Barnett, J. (2018). Consumer acceptance of cultured meat: A systematic review. Meat Science, 143, 8-17. https://doi.org/10.1016/j.meatsci.2018.04.008

Bucic, T., Harris, J., \& Arli, D. (2012). Ethical consumers among the millennials: A cross-national study. Journal of Business Ethics, 110(1), 113-131. https://doi.org/10.1007/s10551-0111151-Z

Bush, C. L., Blumberg, J. B., El-Sohemy, A., Minich, D. M., Ordovás, J. M., Reed, D. G., et al. (2020). Toward the definition of personalized nutrition: A proposal by the American nutrition association. Journal of the American College of Nutrition, 39(1), 5-15. https://doi.org/ 10.1080/07315724.2019.1685332

Business Insider. (2018). UBS: Online food delivery could be a $\$ 365$ billion industry by 2030 - here are the winners and losers from that 'mega trend'. Retrieved from https://www.businessinsider. com/ubs-online-food-delivery-death-of-kitchen-note-2018-7? international =true \&r=US\&IR=T.

Buss, A. R. (1974). Generational analysis: Description, explanation, and theory. Journal of Social Issues, 30(2), 55-71. https://doi.org/10.1111/j.1540-4560.1974.tb00715.x

Butler, D., Holloway, L., \& Bear, C. (2012). The impact of technological change in dairy farming: Robotic milking systems and the changing role of the stockperson. Journal of the Royal Agricultural Society of England, 173, 1-6.

Carson, R. (1962). The silent spring. Boston, MA: Houghton Mifflin.

(CDC), C. f. D. C. a. P. (2018). CDC food safety alert: E. coli outbreak linked to romaine lettuce. Retrieved from https://www.cdc.gov/media/releases/2018/s1120-ecoli-romain-lettuce.html.

Celis-Morales, C., Lara, J., \& Mathers, J. C. (2015). Personalising nutritional guidance for more effective behaviour change. Proceedings of the Nutrition Society, 74(2), 130-138. https:// doi.org/10.1017/S0029665114001633

Celis-Morales, C., Livingstone, K. M., Marsaux, C. F., Macready, A. L., Fallaize, R., O'Donovan, C. B., ... Navas-Carretero, S. (2017). Effect of personalized nutrition on healthrelated behaviour change: Evidence from the Food4me European randomized controlled trial. International Journal of Epidemiology, 46(2), 578-588.

Charlebois, S., \& Haratifar, S. (2015). The perceived value of dairy product traceability in modern society: An exploratory study. Journal of Dairy Science, 98(5), 3514-3525. https://doi.org/ 10.3168/jds.2014-9247

Claudy, M. C., Garcia, R., \& O’Driscoll, A. (2015). Consumer resistance to innovation-a behavioral reasoning perspective. Journal of the Academy of Marketing Science, 43, 528-544. https://doi.org/10.1007/s11747-014-0399-0 (prepublished online).

Costa, A. I.d. A., Schoolmeester, D., Dekker, M., \& Jongen, W. M. F. (2007). To cook or not to cook: A means-end study of motives for choice of meal solutions. Food Quality and Preference, 18(1), 77-88. https://doi.org/10.1016/j.foodqual.2005.08.003

Cox, D. N., \& Evans, G. (2008). Construction and validation of a psychometric scale to measure consumers' fears of novel food technologies: The food technology neophobia scale. Food Quality and Preference, 19(8), 704-710.

Dagevos, H. (2015). Exploring flexitarianism: Meat reduction in a meat-centred food culture. In Impact of meat consumption on health and environmental sustainability (pp. 233-243).

Davis, F. D. (1989). Perceived usefulness, perceived ease of use, and user acceptance of information technology. MIS Quarterly, 13(3), 319-340.

Desai, D. (2019). How democratized production challenges society's ability to regulate. In $3 D$ printing and beyond. Edward Elgar Publishing. 
Diamond, J. (2002). Evolution, consequences and future of plant and animal domestication. $\mathrm{Na}$ ture, 418(6898), 700-707.

Dimock, M. (2019). Defining generations: Where Millennials end and Generation Z begins. Pew Research Center, 17, 1-7.

Driessen, C., \& Heutinck, L. F. (2015). Cows desiring to be milked? Milking robots and the coevolution of ethics and technology on Dutch dairy farms. Agriculture and Human Values, $32(1), 3-20$.

Eurostat. (2020). E-commerce statistics for individuals (Retrieved from).

Evenson, R. E., \& Gollin, D. (2003). Assessing the impact of the green revolution, 1960 to 2000. Science, 300(5620), 758-762.

Ferguson, L. R., De Caterina, R., Görman, U., Allayee, H., Kohlmeier, M., Prasad, C., ... Martinez, J. A. (2016). Guide and position of the international society of nutrigenetics/ nutrigenomics on personalised nutrition: Part 1 - fields of precision nutrition. Lifestyle Genomics, 9(1), 12-27. https://doi.org/10.1159/000445350

Ferrero, R., Vakili, M. G., Giusto, E., Guerrera, M., \& Randazzo, V. (2019). Ubiquitous fridge with natural language interaction. In Paper presented at the 2019 IEEE international conference on RFID technology and applications (RFID-TA).

Fischer, M., \& Himme, A. (2017). The financial brand value chain: How brand investments contribute to the financial health of firms. International Journal of Research in Marketing, 34(1), 137-153. https://doi.org/10.1016/j.ijresmar.2016.05.004

Fischer, A. R. H., \& Reinders, M. J. (2016). Consumer acceptance of novel foods. In C. M. Galanakis (Ed.), Innovation strategies in the food industry (pp. 271-292). London, UK: Academic Press.

Fischer, A. R. H., \& Steenbekkers, L. P. A. (2018). All insects are equal, but some insects are more equal than others. British Food Journal, 120(4), 852-863. https://doi.org/10.1108/BFJ-052017-0267

Fishbein, M., \& Ajzen, I. (1975). Belief, attitude, intention, and behavior: An introduction to theory and research. Reading, MA: Addison-Wesley.

Fishman, A. A. (2016). How generational differences will impact America's aging workforce: Strategies for dealing with aging Millennials, Generation X, and Baby Boomers. Strategic HR Review.

FMI, \& Nielsen. (2018). 70\% of consumers will be grocery shopping online by 2024. Retrieved from https://www.nielsen.com/us/en/press-releases/2018/fmi-and-nielsen-online-groceryshopping-is-quickly-approaching-saturation/.

Fortune, A. (2019). Vion to convert beef facility into plant-based site. GlobalMeat new.com. Retrieved from https://www.globalmeatnews.com/Article/2019/10/30/Vion-to-convert-beeffacility-into-plant-based-site?utm_source=copyright\&utm_medium=OnSite\&utm_campaign= copyright.

Fraser, A. (2019). Land grab/data grab: Precision agriculture and its new horizons. Journal of Peasant Studies, 46(5), 893-912.

Frewer, L. J., Brennan, M., Coles, D., Kleter, G. A., Fischer, A. R. H., Houdebine, L. M., Mora, C., Millar, K., Salter, B., \& Brennan, M. (2013). Genetically modified animals from life-science, socio-economic and ethical perspectives: Examining issues in an EU policy context. New Biotechnology, 30(5), 447-460. https://doi.org/10.1016/j.nbt.2013.03.010

Galvez, J. F., Mejuto, J. C., \& Simal-Gandara, J. (2018). Future challenges on the use of blockchain for food traceability analysis. TRAC Trends in Analytical Chemistry, 107, 222-232. https://doi.org/10.1016/j.trac.2018.08.011 
de Gavelle, E., Davidenko, O., Fouillet, H., Delarue, J., Darcel, N., Huneau, J.-F., et al. (2019). Self-declared attitudes and beliefs regarding protein sources are a good prediction of the degree of transition to a low-meat diet in France. Appetite, 142, 104345. https://doi.org/ 10.1016/j.appet.2019.104345

Gibney, M. J., \& Walsh, M. C. (2013). The future direction of personalised nutrition: My diet, my phenotype, my genes. Proceedings of the Nutrition Society, 72(2), 219-225. https://doi.org/ 10.1017/S0029665112003436

Gimpel, J. (1992). The medieval machine: The industrial revolution of the middle ages. London: Pimlico.

Goddard, E. (2020). The impact of COVID-19 on food retail and food service in Canada: Preliminary assessment. Canadian Journal of Agricultural Economics/Revue canadienne d'agroeconomie. https://doi.org/10.1111/cjag.12243. n/a(n/a).

Gonzalez Fischer, C., \& Garnett, T. (2016). Plates, pyramids, and planets: Developments in national healthy and sustainable dietary guidelines: A state of play assessment (9251092222). Retrieved from.

Grahl, S., Strack, M., Weinrich, R., \& Mörlein, D. (2018). Consumer-oriented product development: The conceptualization of novel food products based on spirulina (Arthrospira platensis) and resulting consumer expectations. Journal of Food Quality, 1919482. https://doi.org/ 10.1155/2018/1919482, 2018.

Guhr, N., Werth, O., Blacha, P. P. H., \& Breitner, M. H. (2020). Privacy concerns in the smart home context. SN Applied Sciences, 2(2), 247.

Gunden, N., Morosan, C., \& DeFranco, A. (2020). Consumers' intentions to use online food delivery systems in the USA. International Journal of Contemporary Hospitality Management, 32(3), 1325-1345. https://doi.org/10.1108/IJCHM-06-2019-0595

Hartmann, C., Shi, J., Giusto, A., \& Siegrist, M. (2015). The psychology of eating insects: A crosscultural comparison between Germany and China. Food Quality and Preference, 44, 148-156. https://doi.org/10.1016/j.foodqual.2015.04.013

Hartmann, C., \& Siegrist, M. (2016). Becoming an insectivore: Results of an experiment. Food Quality and Preference, 51, 118-122. https://doi.org/10.1016/j.foodqual.2016.03.003

Heffernan, O. (2017). Sustainability: A meaty issue. Nature, 544(7651), S18-S20. https://doi.org/ $10.1038 / 544$ S18a

Henriques, A. S., King, S. C., \& Meiselman, H. L. (2009). Consumer segmentation based on food neophobia and its application to product development. Food Quality and Preference, 20(2), 83-91.

Hertz, F. D., \& Halkier, B. (2017). Meal box schemes a convenient way to avoid convenience food? Uses and understandings of meal box schemes among Danish consumers. Appetite, 114, 232-239. https://doi.org/10.1016/j.appet.2017.03.016

Hill, B., \& Maddock, S. (2019). (No) time to cook: Promoting meal-kits to the time-poor consumer. In J. Byrom, \& D. Medway (Eds.), Case studies in food retailing and distribution (pp. 241-253). Woodhead Publishing.

Hillman, G. C., \& Davies, M. S. (1990). Measured domestication rates in wild wheats and barley under primitive cultivation, and their archaeological implications. Journal of World PreHistory, 4(2), 157-222.

von Hippel, E. (1986). Lead users: A source of novel product concepts. Management Science, 32(7), 791-805.

Hobbs, J. E. (2020). Food supply chains during the COVID-19 pandemic. Canadian Journal of Agricultural Economics/Revue canadienne d'agroeconomie. https://doi.org/10.1111/ cjag.12237. n/a(n/a). 
Hoek, A. C., van Boekel, M. A. J. S., Voordouw, J., \& Luning, P. A. (2011). Identification of new food alternatives: How do consumers categorize meat and meat substitutes? Food Quality and Preference, 22(4), 371-383. https://doi.org/10.1016/j.foodqual.2011.01.008

House, J. (2016). Consumer acceptance of insect-based foods in The Netherlands: Academic and commercial implications. Appetite, 107, 47-58. https://doi.org/10.1016/j.appet.2016.07.023

Hussmann, S., Knoll, F. J., Meissner, A., \& Holtorf, T. (2019). Development and evaluation of a low-cost delta robot system for weed control applications in organic farming. In Paper presented at the 2019 IEEE international instrumentation and measurement technology conference (IIMTC).

Ingenbleek, P., \& Zhao, Y. (2019). The vegetarian butcher: On its way to becoming the world's biggest 'meat'producer? The International Food and Agribusiness Management Review, 22(1030-2019-628), 295-308.

IRI. (2019). Winning ahead online E-commerce in FMCG. Retrieved from https://www. iriworldwide.com/IRI/media/IRI-Clients/International/E-commerce-POV.pdf.

Jansson, J., Marell, A., \& Nordlund, A. (2010). Green consumer behavior: Determinants of curtailment and eco-innovation adoption. Journal of Consumer Marketing, 27(4), 358-370.

Jin, S., Zhang, Y., \& Xu, Y. (2017). Amount of information and the willingness of consumers to pay for food traceability in China. Food Control, 77, 163-170. https://doi.org/10.1016/ j.foodcont.2017.02.012

Kaiser, F. G., Schultz, P. W., \& Scheuthle, H. (2007). The theory of planned behavior without compatibility? Beyond method bias and past trivial associations. Journal of Applied Social Psychology, 37(7), 1522-1544.

Kambewa, E. V. (2007). Contracting for sustainability: An analysis of the lake victory-EU nile perch chain. Wageningen, Nl: Wageningen Academic Publishers.

Kamilaris, A., Fonts, A., \& Prenafeta-Boldu, F. X. (2019). The rise of blockchain technology in agriculture and food supply chains. Trends in Food Science \& Technology, 91, 640-652. https://doi.org/10.1016/j.tifs.2019.07.034

Karlsen, K. M., Dreyer, B., Olsen, P., \& Elvevoll, E. O. (2013). Literature review: Does a common theoretical framework to implement food traceability exist? Food Control, 32(2), 409-417. https://doi.org/10.1016/j.foodcont.2012.12.011

Keefe, L. M. (2018). FakeMeat: How big a deal will animal meat analogs ultimately be? Animal Frontiers, 8(3), 30-37.

Keluskar, K. (no date). Fridge-O-Matic.

Khan, S. A., \& Sowards, S. K. (2018). It's not just dinner: Meal delivery kits as food media for food citizens. Frontiers in Communication, 3(39). https://doi.org/10.3389/fcomm.2018.00039

Kim, Y. G., \& Woo, E. (2016). Consumer acceptance of a quick response (QR) code for the food traceability system: Application of an extended technology acceptance model (TAM). Food Research International, 85, 266-272. https://doi.org/10.1016/j.foodres.2016.05.002

Kolkmann, A., Post, M., Rutjens, M., van Essen, A., \& Moutsatsou, P. (2019). Serum-free media for the growth of primary bovine myoblasts. Cytotechnology, 1-10.

Ko, M. H., Ryuh, B.-S., Kim, K. C., Suprem, A., \& Mahalik, N. P. (2014). Autonomous greenhouse mobile robot driving strategies from system integration perspective: Review and application. IEEE/ASME Transactions On Mechatronics, 20(4), 1705-1716.

Lin, H.-C., Bruning, P. F., \& Swarna, H. (2018). Using online opinion leaders to promote the hedonic and utilitarian value of products and services. Business Horizons, 61(3), 431-442. https://doi.org/10.1016/j.bushor.2018.01.010

Lion, R., Willems, A., Fischer, A. R. H., \& van Trijp, H. (2020). Exploring consumers perceptions of additives and flavour enhancers in Germany, China and Philippines. 
Liu, R. F., Gao, Z. F., Nayga, R. M., Snell, H. A., \& Ma, H. Y. (2019). Consumers' valuation for food traceability in China: Does trust matter? Food Policy, 88. https://doi.org/10.1016/ j.foodpol.2019.101768

Liu, C., Li, J. Y., Steele, W., \& Fang, X. M. (2018). A study on Chinese consumer preferences for food traceability information using best-worst scaling. PLoS One, 13(11). https://doi.org/ 10.1371/journal.pone.0206793

Liu, Z., Zhang, M., Bhandari, B., \& Wang, Y. (2017). 3D printing: Printing precision and application in food sector. Trends in Food Science \& Technology, 69, 83-94. https://doi.org/ 10.1016/j.tifs.2017.08.018

Livingstone, K. M., Celis-Morales, C., Navas-Carretero, S., San-Cristobal, R., Macready, A. L., Fallaize, R., ... Food4Me, S. (2016). Effect of an internet-based, personalized nutrition randomized trial on dietary changes associated with the mediterranean diet: The Food4Me study. American Journal of Clinical Nutrition, 104(2), 288-297. https://doi.org/10.3945/ ajcn.115.129049

Martins, N., Morales, P., Barros, L., \& Ferreira, I. C. (2017). The increasing demand for functional foods. Wild plants, mushrooms and nuts: Functional food properties and applications.

Mazzacano D’Amato, P., \& Falzon, J. (2015). Why do some consumers prefer organic food? A discourse Analytical perspective. Journal of Food Products Marketing, 21(3), 255-273. https://doi.org/10.1080/10454446.2013.843487

Mckay, G. A. (2008). Consumption, coca-colonisation, cultural resistance-and Santa Claus.

Menozzi, D., Sogari, G., Veneziani, M., Simoni, E., \& Mora, C. (2017). Eating novel foods: An application of the theory of planned behaviour to predict the consumption of an insect-based product. Food Quality and Preference, 59, 27-34. https://doi.org/10.1016/ j.foodqual.2017.02.001

Meulenberg, M. T. G., \& Viaene, J. (2005). Changing agri-food systems in western countries: A marketing approach. In W. M. F. Jongen, \& M. T. G. Meulenberg (Eds.), Innovation in agrifood systems (pp. 17-51). Wageningen: Wageningen Academic Publishers.

Michel, M., \& Burbidge, A. (2019). Nutrition in the digital age - how digital tools can help to solve the personalized nutrition conundrum. Trends in Food Science \& Technology, 90, 194-200. https://doi.org/10.1016/j.tifs.2019.02.018

Mogili, U. R., \& Deepak, B. (2018). Review on application of drone systems in precision agriculture. Procedia computer science, 133, 502-509.

Moons, I., Barbarossa, C., \& De Pelsmacker, P. (2018). The determinants of the adoption intention of eco-friendly functional food in different market segments. Ecological Economics, 151, 151-161. https://doi.org/10.1016/j.ecolecon.2018.05.012

Moore, M., \& Carpenter, J. M. (2008). Intergenerational perceptions of market cues among US apparel consumers. Journal of Fashion Marketing and Management, 12(3), 323-337. https:// doi.org/10.1108/13612020810889281

Mortimer, G., Fazal e Hasan, S., Andrews, L., \& Martin, J. (2016). Online grocery shopping: The impact of shopping frequency on perceived risk. International Review of Retail Distribution \& Consumer Research, 26(2), 202-223. https://doi.org/10.1080/09593969.2015.1130737

Nash, K. S. (2018). Walmart requires lettuce, spinach suppliers to join blockchain. The Wall Street Journal. https://blogs.wsj.com/cio/2018/09/24/walmart-requires-lettuce-spinach-suppliers-tojoin-blockchain/.

Nguyen, M. H., van Weert, J. C. M., Bol, N., Loos, E. F., Tytgat, K. M. A. J., van de Ven, A. W. H., et al. (2017). Tailoring the mode of information presentation: Effects on younger and older adults' attention and recall of online information. Human Communication Research, 43(1), 102-126. https://doi.org/10.1111/hcre.12097 
Oltvoort, A., de Vries, P., van Rompay, T., \& Rosen, D. (2019). "I Am the eye in the sky-can you read my mind?" How to address public concerns towards drone use. In Paper presented at the international conference on persuasive technology.

Opara, L. U. (2003). Traceability in agriculture and food supply chain: A review of basic concepts, technological implications, and future prospects. Journal of Food Agriculture and Environment, 1, 101-106.

Parker, K., Graf, N., \& Igielnik, R. (2019). Generation Z looks a lot like millennials on key social and political issues. Pew Research Center, 17.

Pliner, P., \& Hobden, K. (1992). Development of a scale to measure the trait of food neophobia in humans. Appetite, 19(2), 105-120.

Post, M. J. (2012). Cultured meat from stem cells: Challenges and prospects. Meat Science, 92(3), 297-301.

Purdy, C. (2019). The first cell-cultured meat will cost about $\$ 50$. Quartz. Retrieved from https:// qz.com/1598076/the-first-cell-cultured-meat-will-cost-about-50/.

Rahman, M. M., Ishii, K., \& Noguchi, N. (2019). Optimum harvesting area of convex and concave polygon field for path planning of robot combine harvester. Intelligent service robotics, 12(2), $167-179$.

Rao, H. (2009). Market rebels and radical innovation. McKinsey Quarterly.

Ray, A., Dhir, A., Bala, P. K., \& Kaur, P. (2019). Why do people use food delivery apps (FDA)? A uses and gratification theory perspective. Journal of Retailing and Consumer Services, 51, 221-230. https://doi.org/10.1016/j.jretconser.2019.05.025

Reinders, M. J., Bouwman, E. P., van den Puttelaar, J., \& Verain, M. C. D. (2020). Consumer acceptance of personalised nutrition: The role of ambivalent feelings and eating context. PLoS One, 15(4), e0231342. https://doi.org/10.1371/journal.pone.0231342

Rodriguez-Salvador, B., \& Dopico, D. C. (2020). Understanding the value of traceability of fishery products from a consumer perspective. Food Control, 112, 107142. https://doi.org/10.1016/ j.foodcont.2020.107142

Rogers, E. M. (1962/1995). Diffusion of innovations. New York: Free Press.

Roh, M., \& Park, K. (2019). Adoption of O2O food delivery services in South Korea: The moderating role of moral obligation in meal preparation. International Journal of Information Management, 47, 262-273. https://doi.org/10.1016/j.ijinfomgt.2018.09.017

Ronteltap, A., Fischer, A. R. H., \& Tobi, H. (2011). Societal response to nanotechnology: Converging technologies-converging societal response research? Journal of Nanoparticle Research, 13(10), 4399-4410. https://doi.org/10.1007/s11051-011-0473-1

Ronteltap, A., Van Trijp, H., Berezowska, A., \& Goossens, J. (2013). Nutrigenomics-based personalised nutritional advice: In search of a business model? Genes and Nutrition, 8(2), $153-163$.

Ronteltap, A., van Trijp, J. C. M., Renes, R. J., \& Frewer, L. J. (2007). Consumer acceptance of technology-based food innovations: Lessons for the future of nutrigenomics. Appetite, 49(1), $1-17$.

Rothensee, M. (2008). User acceptance of the intelligent fridge: Empirical results from a simulation. In Vol. 4952 LNCS. Lecture notes in computer science (including subseries lecture notes in artificial intelligence and lecture notes in bioinformatics).

Rozin, P. (2005). The meaning of "natural": Process more important than content. Psychological Science, 16(8), 652-658.

Saba, A., \& Vassallo, M. (2002). Consumer attitudes toward the use of gene technology in tomato production. Food Quality and Preference, 13(1), 13-21. https://doi.org/10.1016/s09503293(01)00052-0 
Sackmann, R., \& Winkler, O. (2013). Technology generations revisited: The internet generation. Gerontechnology, 11(4), 493-503. https://doi.org/10.4017/gt.2013.11.4.002.00

Sale, K. (1996). Rebels against the future: The luddites and their war on the Industrial revolution, lessons for the computer age. New York: Perseus.

Sander, F., Semeijn, J., \& Mahr, D. (2018). The acceptance of blockchain technology in meat traceability and transparency. British Food Journal, 120(9), 2066-2079. https://doi.org/ 10.1108/BFJ-07-2017-0365

Santos, T. D., Freitas, B. C. B.d., Moreira, J. B., Zanfonato, K., \& Costa, J. A. V. (2016). Development of powdered food with the addition of Spirulina for food supplementation of the elderly population. Innovative Food Science \& Emerging Technologies, 37, 216-220. https:// doi.org/10.1016/j.ifset.2016.07.016

Schenk, M. F., van der Maas, R., Smulders, M. J. M., Gilissen, L. J. W. J., Fischer, A. R. H., Van der Lans, I. A., et al. (2011). Hypoallergenic food products as a novel approach to alleviate mild food allergy. Food Quality and Preference, 22(1), 83-91.

Scherer, R., Siddiq, F., \& Tondeur, J. (2019). The technology acceptance model (TAM): A metaanalytic structural equation modeling approach to explaining teachers' adoption of digital technology in education. Computers \& Education, 128, 13-35. https://doi.org/10.1016/ j.compedu.2018.09.009

Schickenberg, B., Van Assema, P., Brug, J., \& De Vries, N. K. (2008). Are the Dutch acquainted with and willing to try healthful food products? The role of food neophobia. Public Health Nutrition, 11(5), 493-500.

Schwartz, S. H. (1994). Are there universal aspects in the structure and contents of human values? Journal of Social Issues, 50(4), 19-45.

Ścieszka, S., \& Klewicka, E. (2019). Algae in food: A general review. Critical Reviews in Food Science and Nutrition, 59(21), 3538-3547. https://doi.org/10.1080/10408398.2018.1496319

Seehafer, A., \& Bartels, M. (2019). Meat 2.0 - the regulatory environment of plant-based and cultured meat. European Food and Feed Law Review, 14(4), 323-331.

Seitz, C., Pokrivčák, J., Tóth, M., \& Plevný, M. (2017). Online grocery retailing in Germany: An explorative analysis. Journal of Business Economics and Management, 18(6), 1243-1263. https://doi.org/10.3846/16111699.2017.1410218

Siegrist, M. (2000). The influence of trust and perceptions of risks and benefits on the acceptance of gene technology. Risk Analysis, 20(2), 195-204. https://doi.org/10.1111/0272-4332.202020

Siegrist, M. (2008). Factors influencing public acceptance of innovative food technologies and products. Trends in Food Science \& Technology, 19(11), 603-608.

Sparke, K., \& Menrad, K. (2009). Cross-European and functional food-related consumer segmentation for new product development. Journal of Food Products Marketing, 15(3), 213-230. https://doi.org/10.1080/10454440902908142

Steenkamp, J.-B. E., Ter Hofstede, F., \& Wedel, M. (1999). A cross-national investigation into the individual and national cultural antecedents of consumer innovativeness. Journal of Marketing, 63(2), 55-69.

Stephens, J., Miller, H., \& Militello, L. (2020). Food delivery apps and the negative health impacts for Americans. Frontiers in Nutrition, 7. https://doi.org/10.3389/fnut.2020.00014

Suganuma, N. (2019). Trends in the development of autonomous vehicles and challenges for deployment in society. IATSS Research, 43(4), 242-243.

Taebi, B. (2017). Bridging the gap between social acceptance and ethical acceptability. Risk Analysis, 37(10), 1817-1827. https://doi.org/10.1111/risa.12734 
Tan, H. S. G., Fischer, A. R. H., Tinchan, P., Stieger, M., Steenbekkers, L. P. A., \& van Trijp, H. C. M. (2015). Insects as food: Exploring cultural exposure and individual experience as determinants of acceptance. Food Quality and Preference, 42, 78-89. https://doi.org/ 10.1016/j.foodqual.2015.01.013

Tan, H. S. G., Fischer, A. R. H., van Trijp, H. C. M., \& Stieger, M. (2016). Tasty but nasty? Exploring the role of sensory-liking and food appropriateness in the willingness to eat unusual novel foods like insects. Food Quality and Preference, 48, 293-302. https://doi.org/10.1016/ j.foodqual.2015.11.001. Part A.

Tziva, M., Negro, S. O., Kalfagianni, A., \& Hekkert, M. P. (2019). Understanding the protein transition: The rise of plant-based meat substitutes. Environmental Innovation and Societal Transitions. https://doi.org/10.1016/j.eist.2019.09.004

Van Dam, Y. K., \& Fischer, A. R. H. (2015). Buying Green without being seen. Environment and Behavior, 47(3), 328-356. https://doi.org/10.1177/0013916513509481

Van Huis, A., Van Itterbeeck, J., Klunder, H., Mertens, E., Halloran, A., Muir, G., et al. (2013). Edible insects: Future prospects for food and feed security (Vol. 171). Rome: Food and Agriculture Organization of the United Nations.

Van Loo, Caputo, \& Lusk. (2020). Consumer preferences for farm-raised meat, lab-grown meat, and plant-based meat alternatives: Does information or brand matter? Food Policy, Article 101931. https://doi.org/10.1016/j.foodpol.2020.101931. In press.

Van Trijp, H. C. M. (1994). Product-related determinants of variety-seeking behaviour for foods. Appetite, 22(1), 1-10.

Veletsianos, G., Johnson, N., \& Belikov, O. (2019). Academics' social media use over time is associated with individual, relational, cultural and political factors. British Journal of Educational Technology, 50(4), 1713-1728.

Venkatesh, V., \& Bala, H. (2008). Technology acceptance model 3 and a research agenda on interventions. Decision Sciences, 39(2), 273-315.

Venkatesh, V., \& Davis, F. D. (1996). A model of the antecedents of perceived ease of use: Development and test. Decision Sciences, 27(3), 451-477.

Venkatesh, V., \& Davis, F. D. (2000). Theoretical extension of the technology acceptance model: Four longitudinal field studies. Management Science, 46(2), 186-204.

Venkatesh, V., Morris, M. G., Davis, G. B., \& Davis, F. D. (2003). User acceptance of information technology: Toward a unified view. MIS Quarterly: Management Information Systems, 27(3), 425-478.

Venkatesh, V., Thong, J. Y. L., \& Xu, X. (2012). Consumer acceptance and use of information technology: Extending the unified theory of acceptance and use of technology. MIS Quarterly: Management Information Systems, 36(1), 157-178.

Verbeke, W. (2015). Profiling consumers who are ready to adopt insects as a meat substitute in a Western society. Food Quality and Preference, 39, 147-155. https://doi.org/10.1016/ j.foodqual.2014.07.008

Verbeke, W., Sans, P., \& Van Loo, E. J. (2015). Challenges and prospects for consumer acceptance of cultured meat. Journal of Integrative Agriculture, 14(2), 285-294. https://doi.org/10.1016/ S2095-3119(14)60884-4

Verhaal, J. C., Khessina, O. M., \& Dobrev, S. D. (2015). Oppositional product names, organizational identities, and product appeal. Organization Science, 26(5), 1466-1484.

Vermeir, I., \& Verbeke, W. (2006). Sustainable food consumption: Exploring the consumer "attitude - behavioral intention" gap. Journal of Agricultural and Environmental Ethics, 19(2), $169-194$ 
Verplanken, B., \& Orbell, S. (2003). Reflections on past behavior: A self-report index of habit strength. Journal of Applied Social Psychology, 33(6), 1313-1330.

Watson, E. (2019). Plant-based and cell-cultured 'meat' labeling under attack in 25 states. Food Navigator. Retrieved from https://www.foodnavigator-usa.com/Article/2019/05/29/Plantbased-and-cell-cultured-meat-labeling-under-attack-in-25-states.

van der Weele, C., \& Tramper, J. (2014). Cultured meat: Every village its own factory? Trends in Biotechnology, 32(6), 294-296.

WHO. (2015). Food-based dietary guidelines. The Netherlands. Retrieved from http://www.fao. org/nutrition/education/food-dietary-guidelines/regions/countries/Netherlands/en.

WHO. (2017). The burden of foodborne diseases in the WHO European Region. Retrieved from http://www.euro.who.int/en/health-topics/disease-prevention/food-safety/publications/2017/ the-burden-of-foodborne-diseases-in-the-who-european-region-2017.

WHO. (2018). Noncommunicable diseases - key facts. Retrieved from https://www.who.int/newsroom/fact-sheets/detail/noncommunicable-diseases.

Wilks, M., \& Phillips, C. J. C. (2017). Attitudes to in vitro meat: A survey of potential consumers in the United States. PLoS One, 12(2), e0171904. https://doi.org/10.1371/ journal.pone.0171904

Williams, L. A. (2019). Top ten trends for 2020 [Webinar]. Retrieved from https://www. foodingredientsfirst.com/Webinars/top-ten-trends-2020.html.

Xiong, H., Dalhaus, T., Wang, P., \& Huang, J. (2020). Blockchain technology for agriculture: Applications and rationale. Frontiers in Blockchain, 3(7). https://doi.org/10.3389/ fbloc. 2020.00007

Yamoah, F. A., \& Acquaye, A. (2019). Unravelling the attitude-behaviour gap paradox for sustainable food consumption: Insight from the UK apple market. Journal of Cleaner Production, 217, 172-184.

Zhang, C., Bai, J., \& Wahl, T. I. (2012). Consumers' willingness to pay for traceable pork, milk, and cooking oil in Nanjing, China. Food Control, 27(1), 21-28. https://doi.org/10.1016/ j.foodcont.2012.03.001

Zhang, G., Zhao, X., Li, X., Du, G., Zhou, J., \& Chen, J. (2020). Challenges and possibilities for bio-manufacturing cultured meat. Trends in Food Science \& Technology, 97, 443-450. https:// doi.org/10.1016/j.tifs.2020.01.026 